\title{
Zeolite: A Soil Conditioner
}

\section{Binod Kalita $^{1^{*}}$, Sarat Sekhar Bora ${ }^{2^{*}}$ and Bhabesh Gogoi ${ }^{3}$}

${ }^{1}$ Agronomy, RARS, Shillongani, ${ }^{2}$ Agrometeorology, KVK, Udalguri,

${ }^{3}$ Soil Science, AICRP on IFS, Assam Agricultural University, Jorhat-785013, Assam, India

*Corresponding author

\section{Keywords}

Food, Security, Zeolite, Fertilizer

Article Info

Accepted:

15 December 2019

Available Online:

20 January 2020

\section{A B S T R A C T}

In many parts of the world food security is being affected due to declining quality and/or quantity of the soil resource base and climate change. In this context, farming with zeolites has drawn attention. Zeolites are natural aluminosilicates present in rocks in different part of the world. Use of zeolite has gained a momentum in the recent past owing to multitude of benefits accrued from them. Clinoptilolite Zeolites are useful in agriculture because of their large porosity, cation exchange capacity and selectivity for ammonium and potassium cations. They can be used both as carriers of nutrients and as a medium to free nutrients. (C, Sangeetha and P, Baskar, 2016).Natural zeolites has been reported to be used extensively as amendments for sandy soils. Zeolitic amendment is an effective way to improve soil condition in arid and semiarid environments (Yasuda et al., 1998). It was also found that application of soil amendments such as Clinoptilolite zeolite with composted manure improves soil physical properties such as soil CEC. Inorganic and organic fertilizer along with Clinoptilolit Zeolite showed the best $\mathrm{N}, \mathrm{P}$ and $\mathrm{K}$ uptake in plant tissues because of less leaching of these nutrients and helps to retain nutrients in root zone by enhancing nutrient absorption. (Ahmed, 2010).Zeolites could be used as an effective additive to control the odour as they could adsorb the volatile substances like acetic acid, butanoic acid, isovaleric acid, indole and enhances effectiveness of the manure (Leggo, 2000).Zeolite acts as a superior substrate or carrier for the nutrients or acts as a slow-release source of nutrients to plants assuring higher yields. The nano-sized zeolite is capable of retaining $\mathrm{Zn}$ and releasing slowly into the soil solution, which may serve as a slow release $\mathrm{Zn}$ fertilizer and improve use efficiency by crops (Yuvaraj et al., 2018). The effect of zeolite and its combination with chemical fertilizer (NPK) and organic fertilizers (sugarcane filter cake) showed improved soil quality and increased sugarcane yield as compared to control (without fertilization) (Cairo et al., 2017). Although considerable research has been advanced, further research needs to be carried out for their efficient utilization in farming. 


\section{Introduction}

Farming with natural rocks and minerals is an age-old practice for food production since stone ages. The intensive production practices concomitant with imbalanced fertilizer management practices has led to declining quality and/or quantity of the soil resource base and climate change. To feed the growing population, soil degradation is the key issue which needs urgent attention. (C, Sangeetha and $\mathrm{P}$, Baskar, 2016).

As agriculturalists the world over increase their effort to expand crop and animal production, more and more attention is being paid to various mineral materials as soil amendments and as dietary supplements in animal husbandry. The close relationship between the agricutural and geological sciences is not new and crop production depends on the existence and maintenance of fertile soil of clays and other soil constituents. In the animal sciences, the addition of crushed limestone to chicken feed to strengthen egg shells is well known, as is the use of bentonite as a binding agent in pelletized animal feed stuffs. Recently, one group of minerals has emerged as having considerable potential in a wide variety of agricultural processes. This group of minerals is the zeolite group. The unique ion-exchange, dehydrationrehydration, and ad-sorption properties of zeolite materials promise to contribute significantly to many years of agricultural and aquacultural technology.

Most of the initial research on the use of zeolites in agriculture took place in the 1960s in Japan, Japanese farmers have used zeolite rock for years to control the moisture content and malodor of animal wastes and to increase the $\mathrm{pH}$ of acidic volcanic soils. The addition of small amounts of the Zeolites such as clinoptilolite and mordenite to the normal protein diet of pigs, chickens, and ruminants gave noticeable increases in the body weight and general "health" of the animals. The use of zeolites in rations also appeared to reduce odor and associated pollution problems and to provide a means of regulating the viscosity and nitrogen retentivity of animal manure. These same zeolites were also found to increase the ammonium content of rice paddy soils when added with normal fertilizers.

Although most of these were preliminary results and often published in rather obscure journals or reports from local experiment stations, they did suggest that zeolites could act as traps or reservoirs for nitrogen both in the body and in the soil. The growing awareness of such phenomena and of the availability of inexpensive natural zeolites in the Western United States and in geologically similar parts of the world has aroused considerable commercial interest. Zeolites are fast becoming the subject of serious investigation in dozens of agricultural laboratories both here and abroad. In this context, farming with natural zeolites has assumed to be great significance. (Rhodes, C., 2010)

\section{Zeolites of India}

Natural zeolite minerals in India were reported inamygdaloidal vesicles in the Deccan lava flows. Since the 1970s, the state of Maharashtra has provided zeolites thathave come out of the enormous lava flows called the Deccan Traps were reported way back in the 18th century itself, regarding their formation and distributionin the lava flows. These minerals do not occur everywhere in the Western Deccan Traps, but are restricted to certain localities around Mumbai (Bombay), Vadodara (Baroda), Pune (Poona), and Nasik. Heulandites (most popular Zeolites of the world) zone was found in the highlands of plateauin the region around Pune (Maharashtra), which is the top-most region 
up to the highest point Kalsubai. In this region, around $30 \%$ of the rock is occupied by Zeolites (Phadke, 1984). An area of 4.2 million $\mathrm{km}^{2}$ situated betweenlatitudes $0^{\circ}$ and $20^{\circ} \mathrm{S}$ and longitude $70^{\circ}$ and $84^{\circ} \mathrm{E}$ ofthe central Indian basin contained zeolites. In addition to Maharashtra, zeolite occursas filling in the amygdularcavites in deccantrapbasalts of Gujarat, Madhya Pradesh and Karnataka too (Ramesh et al., 2015).

\section{Etymology, nature and properties}

Identification of zeolitesas a mineral goes back to 1756 , when a Swedish mineralogist, Alex Fredrik Cronstedt, collected some crystals from a copper mine in Sweden. Zeolites mean 'boiling stones' in Greek, because of their ability to froth when heated to about $200^{\circ} \mathrm{C}$. Thereafter, zeolites were considered as a mineral found in volcanic rocks for a period of 200 years. Their commercial production and use started in the 1960s.

Different combinations of $\mathrm{SiO}_{4}{ }^{4}$ and $\mathrm{Al}$ $(\mathrm{OH})_{3}{ }^{6-}$ tetrahedral lead to the formation of a three-dimensional framework with pores and voids of molecular dimension. Shape, dimensions and linkage of zeolite pores and voids are the key characteristics of zeolite materials. The pores and interconnected voids are occupied by cations and watermolecules. The structure of each zeolite mineral is complex, but they all have large open 'channels' in the crystal structure that provide a large void space for the adsorption and exchange of cations. The internal surface area of these channels is reported to reach as much as several hundred square metres per gram of zeolite, making zeolite an extremely effective ion exchange. Cations can be changed by ion exchange and water can be removed reversibly by application of heat. The mineral has a three-dimensional crystal lattice, with loosely bound cations, capable of hydrating and dehydrating without altering the crystal structure. Other useful chemical and physical properties include: high void volume $(\sim 50 \%)$, low density $\left(2.1-2.2 \mathrm{~g} / \mathrm{cm}^{3}\right)$, excellent molecular sieve properties and high cation exchange capacity (CEC) of 150-250 $\mathrm{cmol} / \mathrm{kg}$ ), cation selectivity, specifically for cations likeammonium, potassium, cesium, etc.

The kinetics of ion-exchange process in zeolites has been extensively studied. Two processes have been identified, viz. particle diffusion and film diffusion. Diffusion within the zeolite (particle diffusion) and diffusion transport through the liquid film surrounding the particle (film diffusion) have been assumed to be the most important steps in the ion-exchange process. The preference of a zeolite for a particular cation in a multicomponent system depends on various factors, viz. Si/Al ratio of the zeolite, the exchangeable cation of the starting zeolite (co-ions), the hydration ratio of the co-ion and the in-going ions as well as the temperature and three-dimensional framework of zeolite. Therefore, these features should be analysed for a better understanding of the multicomponent ion exchange mechanism.

\section{Structure of Zeolite}

Zeolites are composed of pores andcorner sharing aluminosilicate $\left(\mathrm{AlO}_{4}\right.$ and $\left.\mathrm{SiO}_{4}\right)$ tetrahedrons, joined into three dimensional frameworks. The pore structure is characterized by cages approximately $12 \AA$ in diameter, which are interlinked through channels about $8 \AA$ in diameter, composed of rings of 12 linked tetrahedrons. The pores are interconnected and form long wide channels of varying sizes depending on the mineral. These channels allow the easy movement of the resident ions and molecules into and out of the structure. Zeolites have large vacant spaces or cages within and resemble 
honeycomb or cage like structures. The presence of aluminium results in a negative charge, which is balanced by positively charged cations. The general empirical formula, which represents a zeolite chemical structure, is shown below: $\mathrm{M}_{2} \mathrm{nO} \cdot \mathrm{Al}_{2} \mathrm{O}_{3} \cdot \mathrm{XSiO}_{2} \cdot \mathrm{yH}_{2} \mathrm{O}$

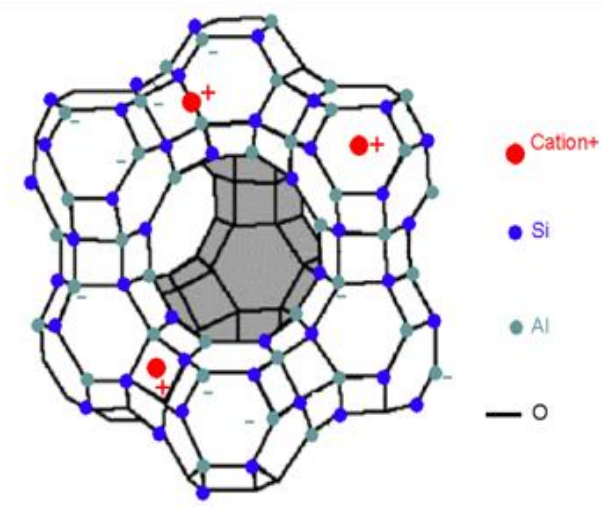

Fig.1 Zeolite chemical structure

$\mathrm{M}$ represents any alkali or alkaline earth cation, $\mathrm{n}$ the valence of the cation, $\mathrm{x}$ varies between 2 and 10, and y varies between 2 and 7 , with structural cations comprising $\mathrm{Si}, \mathrm{Al}$ and $\mathrm{Fe}^{3+}$, and exchangeable cations $\mathrm{K}, \mathrm{Na}$ and Ca (Sheppard and Mumpton,1981); (Hemingway and Robie,1984). Tetrahedral $\mathrm{AlO}_{4}{ }^{-5}$ and $\mathrm{SiO}_{4}{ }^{-4}$ bound by oxygen atoms to form tectosilicatescalled Zeolites.

\section{Application of natural zeolites is based on other chemical properties}

\section{Cation exchange}

The ability to exchange inherent cations for other cations on a basis of ion selectivity.High CEC for heavy metal cations that can be removed from liquid effluents through the process of ion-exchange. These cations include $\mathrm{Pb}, \mathrm{Hg}, \mathrm{Cd}, \mathrm{Co}, \mathrm{Zn}, \mathrm{Cu}, \mathrm{Ag}, \mathrm{Mg}, \mathrm{Fe}$, $\mathrm{Al}, \mathrm{Cr}$ and others.

\section{Adsorption and related molecular sieving}

The adsorption process is fully reversible and of purely physical nature. The adsorption on molecular sieves is therefore dependent on the following physical molecular properties: Size and Shape: molecules or ions larger than the pore opening of the zeolite cannot be adsorbed, smaller molecules or ions can. Molecular Polarity: due the charge on outer and inner zeolitic surface particle, molecules with large polarity can be adsorbed preferentially under identical conditions.

\section{Dehydration and rehydration}

\section{Biological activity}

Natural zeolite has been shown to exhibit diverse biological activities and has been used successfully for the treatment in medical therapy, promotes better plant growth by improving the value of fertilizer, helps preventing the plant from burning, that can be caused by over use of fertilizer, by trapping and slowly releasing valuable nutrients. As additive in concentrated animal growing facilities improve feed conversion, reduce airborne ammonia up to $80 \%$, act as a mycotoxin binder, and improve bone density, it can be used in general odour elimination for all animal odours.

\section{Surface modification of natural zeolite}

Modifying the surface of Zeolites with longchain quaternary amines allowed it to adsorb benzene, toluene, and xylene in the presence of water. Surface modified natural zeolites remove toxic compounds from animal food. Natural zeolite can be treated further with additional amine to produce anion exchangers capable of taking up chromate, arsenate, selenate, and other metal oxyanions from aqueous solutions. 


\section{Classification}

More than 50 different species of thismineral group have been identified. Zeolites have been classified on the basis of their morphological characteristics, crystal structure, chemical composition, effective pore diameter and natural occurrence. Zeolites are classified on the basis of silica: alumina ratio as follows:

(i) Low $\mathrm{Si}: \mathrm{Al}$ ratio, between 1 and 1.5 - zeolite A;

(ii) Intermediate $\mathrm{Si}: \mathrm{Al}$ ratio, between 2 and 5 - zeolite Y;

(iii) High $\mathrm{Si}: \mathrm{Al}$ ratio from 10 to several thousand - erionite, mordenite.

In 1997, the Subcommittee on zeolites of the International Mineralogical Association, Commission on New Minerals and Mineral Names had recommended nomenclature for zeolite minerals. The report suggested that zeolite species are not to be distinguished solely on the $\mathrm{Si}$ : Al ratio, except for heulandite ( $\mathrm{Si}: \mathrm{Al}<4.0)$ and clinoptilolite ( $\mathrm{Si}$ : Al e" 4.0). Dehydration, partial hydration and over hydration are not sufficient grounds for the recognition of separate species of zeolites.Later, Flanigen (2001) has classified zeolites based on pore diameter.

(i) Small-pore zeolites (8 rings) with free pore diameter 0.3 $0.45 \mathrm{~nm}$.

(ii) Medium-pore zeolites (10 rings) with free pore diameter $0.45-0.6 \mathrm{~nm}$.

(iii) Large-pore zeolites (12 rings) with free pore diameter 0.6 $0.8 \mathrm{~nm}$.

(iv) Extra largepore zeolites (14 rings) with free pore diameter $0.8-1.0 \mathrm{~nm}$.

\section{How Zeolites Forms}

Natural zeolites are produced by the forces of volcanism (Figure 2), and are often associated with mountainous regions, e.g. the Caucasus and the Balkans, while there are also deposits found in the Himalayas and in Switzerland, and in the U.S. around the Gulf of Mexico (including Cuba), which has a volcanic history. When molten magma, the force of which pushes up mountains, can escape through a volcanic vent, the volcanic rocks (solidified lava) and ash layers that are produced may transform (crystallize) into a zeolite if they come into contact and reaction with alkalineysaline lake or ground-waters. Beds of zeolites may be hundreds of meters thic. Zeolites have also crystallized in postdepositional environments over periods ranging from thousands to millions of years in shallow marine basins, and are found in some ocean sediments. Naturally occurring zeolites are rarely pure and are contaminated to varying degrees by other minerals, metals, quartz or other zeolites. For this reason, naturally occurring zeolites are excluded from many important commercial applications where uniformity and purity are essential. (Frederick A. Mumpton, Chapter VIII)

\section{Natural Zeolites - Uses:}

Petrochemical industry

Nuclear Industry

Medical-medicine

Heating and refrigerator

Detergent

Construction

Petroleum Refinery

Animal Welfare

Wastewater treatment

Pozzolanic Material in Cement and Concrete Composites

Zeolites in Food Processing Industries

Zeoponic system

Air Separation and Pollution Control 
Aquaculture / Fisheries

Agriculture as a soil conditioner

\section{How NZ act as a Soil Conditioner}

Improving soil physical properties and chemical properties

As a Soil Amendments

Nitrogen management

Phosphorus management

Organic manure handling and

management

Slow release of herbicides

Slow release of nutrient

Soil Microbial population

Plant growth

\section{Details Results and Discussion of Experiment described below}

\section{Improving soil physical properties and chemical properties}

Zeolites have been reported to improve the soil physical properties. They may hold water more than half of their weight due to high porosity of the crystalline structure. Water molecules in the pores could easily be evaporated or reabsorbed without damage to such structures. Zeolites assure a permanent water reservoir. Providing prolonged moisture dry periods helps plants to withstand dry spell; they also promote a rapid rewetting and improve the lateral spread of water into the root zone during irrigation. This results in saving water needed for irrigation. Amendment of sand with zeolite increases available water to the plants by $50 \%$

\section{Case Study 1}

The study was plotted in the sugarcane growing areas of the northern coast of Villa Clara province. Different zeolite levels and combinations with organic fertilizers were applied in Vertisols (Table 3). The
Experiment was set up as a randomized complete block design with 9 treatments and 4 replications. The individual plot sizes were $10 \times 9.6 \mathrm{~m}$. Sugarcane variety Ja $60-5$ was used and was planted in furrows at $1.60 \mathrm{~m}$ row spacing. Organic fertilizer (sugarcane filter cake-SFC), and natural mineral (zeolite$Z$ ) and chemical fertilization (nitrogenphosphorus-potassium-NPK) were applied. The treatments were: T1- control (without application of fertilizer), T2- Z $7.5 \mathrm{t} \mathrm{ha}^{-1}$, T3Z $15 \mathrm{t} \mathrm{ha}^{-1}$, T4- Z $7.5 \mathrm{t} \mathrm{ha}^{-1}+100 \mathrm{~kg} \mathrm{ha}^{-1}$, T5Z $15 \mathrm{t} \mathrm{ha}^{-1}+\mathrm{N} 100 \mathrm{~kg} \mathrm{ha}^{-1}$, T6- Z $7.5 \mathrm{t} \mathrm{ha}^{-1}+$ SFC $22.5 \mathrm{t} \mathrm{ha}^{-1,}$ T7- Z $3 \mathrm{t} \mathrm{ha}^{-1}+$ SFC $18 \mathrm{t} \mathrm{ha}^{-1}$, T8- Z $7.5 \mathrm{t} \mathrm{ha}^{-1}+$ NPK (100-60-200 kg ha-1), T9- Z $7.5 \mathrm{t} \mathrm{ha}^{-1}+$ NPK (100-60-200 kg ha$\left.{ }^{1}\right)$.Significant effects on organic matter and structure were observed. Treatment, Z $7.5 \mathrm{t}$ $\mathrm{ha}^{-1}+$ SFC $22.5 \mathrm{t} \mathrm{ha}^{-1}$ (T6) showed the best result, where 3 of the indicators (organic matter, water-stable aggregates and degree of soil aggregation) reached the highest values. (Pedro Cairo, 2017)

Fig.6shows the soil water regime by comparing the control treatment (T1) with the soil treated with Z $7.5 \mathrm{t} \mathrm{ha}^{-1}+$ SFC $22.5 \mathrm{t} \mathrm{ha}^{-1}$ (T6), when sampling moisture is carried up from a meter deep after $25 \mathrm{~mm}$ of rainfall.

In control treatment, water accumulated on the surface, remaining much drier in depth, due to the limited speed of water infiltration. However, treatment of soil with zeolite guarantees the uptake of rainwater in depth, due to the structural changes (Table 3), which is synonymous with a better use of rainwater and subsequent supply of assimilable water to plants. In the natural soils, all the detained superfluous water is lost by evaporation surface area which may be decisive in cane yield. The results show that the effect of the zeolite and its combination with organic fertilizer not only has its influence on the topsoil but also in depth. (Pedro Cairo, 2017). 


\section{Case Study 2}

A field study was carried out at the Share Farm of Universiti Putra Malaysia Bintulu Sarawak Campus,Malaysia (latitude $3^{\circ} 30^{\prime} \mathrm{N}$, longitude $\left.113^{\circ} 09^{\prime} \mathrm{E}\right)$. The study area is a humid tropic with yearly average oflow and high temperatures of $23^{\circ} \mathrm{C}$ and $34^{\circ} \mathrm{C}$, respectively. A field study was carried out from $10^{\text {th }}$ April 2014 to $21^{\text {st }}$ June 2014 for first planting cycle and $25^{\text {th }}$ Juneto $27^{\text {th }}$ August 2014 for second planting cycle of Zea mays L. These planting periods were considered short term because compost and clinoptilolite zeolite were applied before planting. Longterm effects involve repeated or regular application of amendments for many years. The experimental plots were arranged in a randomized complete block design (RCBD) with three blocks (replications). Thai Super Sweet hybrid F1 variety was used as the test crop. Treatments evaluated in the field study were:

(i) Soil only (control) (T0)

(ii) $7.40 \mathrm{~g}$ urea $+5 \mathrm{~g} \mathrm{TSP}+3.80 \mathrm{~g} \mathrm{MOP}$ (T1)

(iii) $7.40 \mathrm{~g}$ urea $+5 \mathrm{~g}$ TSP $+3.80 \mathrm{~g} \mathrm{MOP}$ +192 g clinoptilolite zeolite (T2)

(iv) $5.55 \mathrm{~g}$ urea $+3.75 \mathrm{~g} \mathrm{TSP}+2.85 \mathrm{~g}$ MOP + $385 \mathrm{~g}$ compost $+192 \mathrm{~g}$ clinoptilolite zeolite (T3)

(v) $3.70 \mathrm{~g}$ urea $+2.50 \mathrm{~g} \mathrm{TSP}+1.90 \mathrm{~g}$ $\mathrm{MOP}+577 \mathrm{~g}$ compost $+192 \mathrm{~g}$ clinoptilolite zeolite (T4)

From the Fig. $7 \& 8$ it can be said that the treatments with rice straw compost and clinoptilolite zeolite (T2, T3, and T4) significantly improved soil total organic $\mathrm{C}$ and organic matter (Figure 4) because they increased total $\mathrm{N}$, exchangeable $\mathrm{NH} 4+$, and available $\mathrm{NO} 3-$. Increase in soil $\mathrm{N}$ facilitates decomposition of composts to release more $\mathrm{C}$ and humus.(Omar et al., 2018)

\section{As soil amendment}

Zeolites consist of cage-like polyhedral units with a high cation-exchange capacity and internal pores in crystal lattices that result in high water adsorption and nutrient retention Zeolite does not break down over time, but remains in the soil to improve nutrient retention. Therefore, its addition to the soil may significantly reduce water and fertilizer costs by retaining beneficial nutrients in the root zone. The porous structure of natural zeolite helps keep the soil aerated and moist as well as active for a long time. Natural zeolites have been reported to be used extensively in Japan as amendments for sandy soils, and small tonnages have been exported to Taiwan for this purpose. Zeolitic amendment is an effective way to improve soil condition in an arid and semiarid environment. Zeolites have been tested for use as a soil amendment on various crops, including vegetables and in greenhouses in Russia, field crops in Japan, as constituents of golf course greens and tees in order to improve drainage and aeration, to improve compaction resistance, and reduce leaching of pesticides and fertilizers from the soil. Zeolites increase the water-retention capacity of the soils.

The higher the average ionic potential of the extra- framework cations, the larger the hydration capacity of the clinoptilolite. This trend may be attributed to the small size as well as the efficient water-cation packing of high field strength cations in the zeolite structure.

\section{Case Study3}

An experiment was carried out at Share Farm ofUniversity Putra Malaysia of Bintulu Campus, Sarawak in Maize plant with organic, inorganic and Zeolites, where soil chemical properties were studied. 
From the above table 4 it can be says that the addition of chemical fertilizer and compost along with Clinoptilolite zeolite affect different natural processes in the soil where compost enhances the organic matter percentage of soil. Increase in soil $\mathrm{pH}$ increases the availability of soil nutrients for the maize plant. (Ahmed, 2010)

\section{Case Study 4}

The experiment was conducted on sandy loam soil during the 2008 and 2009 growing seasons at the research farm of TarbiatModares University, Tehran, Iran $(358410 \mathrm{~N}, 518190 \mathrm{E}$ and $1215 \mathrm{masl})$. The region is characterized as semi-arid, with mean annual precipitation of $298 \mathrm{~mm}$, which mostly falls during the autumn and winter month in Sunflower crop with 4 treatment combination which is given in Table 5.

From the above table it can be says that Irrigation water productivity describes the quantitative relation between plant growth and water consumption. It is defined as dry matter produced $(\mathrm{kg})$ per unit of water consumption (m3). It isshows that in both years, the F5 treatment hadgreater IWP than the F1 treatment. In other words, water useefficiency increased during limited water conditions. For the F1treatment, IWP was lower due to increased water deep percolationand evaporation. In integrated treatments with zeolite (F3, F4and F5), application of manure increased soil water retentioncapacity. This effect is due to hydrophiliccomponents of manure, such as polysaccharides.Furthermore, zeolite improved growth and development of plants and increased dry matter production by prolonging $\mathrm{N}$ availability.Thus, the higher IWP in integrated treatments with zeolite can beexplained by two separate processes: increased water retentiondue to manure application and better plant growth and developmentdue to the presence of zeolite.(Majid et al., 2013)

\section{Case Study 5}

A field study was carried out at the Share Farm of Universiti Putra Malaysia Bintulu Sarawak Campus, Malaysia (latitude $3^{\circ} 30^{\prime} \mathrm{N}$, longitude $\left.113^{\circ} 09^{\prime} \mathrm{E}\right)$. The study area is a humid tropic with yearly average of low and high temperatures of $23^{\circ} \mathrm{C}$ and $34^{\circ} \mathrm{C}$, respectively. A field study was carried out from 10th April 2014 to 21st June 2014 for first planting cycle and 25th Juneto 27th August 2014 for second planting cycle of Zea mays L. These planting periods were considered short term because compost and clinoptilolite zeolite were applied before planting. Long-term effects involve repeated or regular application of amendments for many years. The experimental plots were arranged in a randomized complete block design (RCBD) with three blocks (replications). Thai Super Sweet hybrid F1 variety was used as the test crop. Treatments evaluated in the field study were

(i) Soil only (control) $\left(\mathrm{T}_{0}\right)$

(ii) $7.40 \mathrm{~g}$ urea $+5 \mathrm{~g} \mathrm{TSP}+3.80 \mathrm{~g} \mathrm{MOP}\left(\mathrm{T}_{1}\right)$

(iii) $7.40 \mathrm{~g}$ urea $+5 \mathrm{~g} \mathrm{TSP}+3.80 \mathrm{~g} \mathrm{MOP}+$ 192 g clinoptilolite zeolite $\left(\mathrm{T}_{2}\right)$

(iv) $5.55 \mathrm{~g}$ urea $+3.75 \mathrm{~g} \mathrm{TSP}+2.85 \mathrm{~g} \mathrm{MOP}+$ 385 g compost +192 g clinoptilolite zeolite $\left(\mathrm{T}_{3}\right)$

(v)3.70 g urea +2.50 g TSP +1.90 g MOP + 577 g compost +192 g clinoptilolite zeolite $\left(\mathrm{T}_{4}\right)$

It might be due to the Soil CEC significantly improved with $\mathrm{T}_{2}, \mathrm{~T}_{3}$, and $\mathrm{T}_{4}$ (Table 5) because of the inherent CEC of the ricestraw compost and clinoptilolite zeolite. Composts improve soil CEC because of the affinity of their humic acids and fulvic acids for positively charged multivalent ions such as $\mathrm{K}^{+}, \mathrm{Ca}^{2+}$, andMg ${ }^{2+}$. The negatively charged 
aluminosilicates of the clinoptilolite zeolite are also responsible for theimproved soil CEC. The treatments with rice straw compost and clinoptilolitezeolite $\left(\mathrm{T}_{2}, \mathrm{~T}_{3}\right.$, and $\left.\mathrm{T}_{4}\right)$ increased soil $\mathrm{pH}$ (Table 5) because of the relatively high $\mathrm{Ca}$ and $\mathrm{Mg}$ of the amendments. Soil incubation and leaching experiments had shown that rice strawcompost and clinoptilolite zeolite can mitigate soil acidity. (Omar et al., 2018)

\section{Nitrogen management}

Although nitrogen is regarded as king pin in agriculture and widely used in all crops and cropping system, its use efficiency is just 30$40 \%$ only. Urea impregnated zeolite chips have also been developed, found increased nitrogen-use efficiency in rice owing to application of zeolites and ensured good retention of soil-exchangeable cations, available $\mathrm{P}$ and $\mathrm{NO}_{3}$ within the soil in maize at Malaysia (Rabai et al., 2013).

\section{Case Study6}

An experiment was carried out at Share Farm ofUniversity Putra Malaysia of Bintulu Campus, Sarawak in Maize plant with organic, inorganic and Zeolites, where soil chemical properties were studied.

From the above result it can be seen that Treatments with zeolite showed the best N, P and $\mathrm{K}$ uptake in plant tissues because of less leaching of these nutrients. Zeolites help to retain nutrients in root zone and, therefore, improving the long term soil quality by enhancing nutrient absorption (Ahmed et al., 2010).

\section{Case Study7}

The experiment was conducted on sandy loam soil during the 2008 and 2009 growing seasons at the research farm of
TarbiatModares University, Tehran, Iran (358410N, 518190E and 1215 masl). The region is characterized as semi-arid, with mean annual precipitation of $298 \mathrm{~mm}$, which mostly falls during the autumn and winter month in Sunflower crop with 4 treatment combination which is given in Table 8 .

Both year it can be seen that the treatment F5 shows the lowest nitrogen leaching as compare to treatment $\mathrm{F} 1$, it might be due to the not only cattle manure responsible for improved the soil condition but zeolite has the potential role to reduced the nitrogent leaching by capturing the nitrogen in its honeycomb structure and made available to plant.(Majid et al., 2013)

\section{Case Study8}

This study was conducted from December 2013 to March 2014 at the greenhouse of ShahidChamran University of Ahvaz, Iran, in a completely randomized design, with a factorial arrangement of treatments in three replications. The treatments consisted of $\mathrm{Z} 0$ (control): $100 \mathrm{~kg}$ ha-1 urea fertilizer; Z1: 0.5 $\mathrm{g} \mathrm{kg}-1$ raw zeolite $+100 \mathrm{~kg}$ ha-1 urea fertilizer; Z2: $1 \mathrm{~g} \mathrm{~kg}-1$ raw zeolite $+100 \mathrm{~kg}$ ha-1 urea fertilizer; Z3: $0.5 \mathrm{~g} \mathrm{~kg}-1 \mathrm{NH} 4+-$ zeolite $+80 \mathrm{~kg}$ ha-1urea fertilizer; and Z4: 1 g kg- $1 \mathrm{NH} 4$ +-zeolite $+60 \mathrm{~kg}$ ha-1 urea fertilizer, all of which were applied to two types of soil with clay loam and sandy loam textures. The steps of the study included the preparation of $\mathrm{NH} 4$ +-zeolites in the laboratory, wheat cultivation in the greenhouse and finally the collection of drainage waters followed by the analysis of the yield of wheat and nitrogen leaching in the different treatments.

For a given means within each column of each section followed by the same letter are not significantly different $(p \leq 0.05)$ 
Mean comparison of grain yield and total $\mathrm{N}$ in shoots of the wheat plants influenced by zeolite treatments and soil texture is shown in Table 9. Nitrogen uptake by plants in soils treated with $\mathrm{Z} 0$ (only $\mathrm{N}$ fertilizer) and $\mathrm{Z4}$ (NH4 +-enriched zeolite) was significantly higher than those of Z2 (raw zeolite), because an amount of $\mathrm{N}$ was absorbed by the raw zeolites and was unavailable for plants, thus reducing the percentage of $\mathrm{N}$ uptake in the growing plants. Application of materials with properties of zeolite probably causes a slow and controlled $\mathrm{N}$ release. Although these properties reduce the plant nitrogen uptake, they can prevent the loss of nitrogen from soil.(Mehrab et al., 2018)

\section{Phosphorus management}

$\mathrm{CZ}$ properties, such as it being alkaline and having negative charges, can be used to improve $\mathrm{P}$ availability through amelioration of soil $\mathrm{pH}$, reduction of soil acidity, soil exchangeable Al, and soil exchangeable Fe.In addition, $\mathrm{CZ}$ incorporation into crop fertilization programs may trigger induceexchange dissolution mechanisms that release $\mathrm{P}$ through uptake of nutrients by the plant. Phosphorus release demonstrated by exchange-induced dissolution system is as follows - $\mathrm{RP}+\mathrm{NH}_{4}{ }^{+}+\mathrm{CZ}$------- $\mathrm{Ca}-\mathrm{CZ}+$ $\mathrm{NH}_{4}{ }^{+}+\mathrm{H}_{2} \mathrm{PO}_{4}{ }^{-}$This will result in less $\mathrm{P}$ being fixed by metal oxy-hydroxides.

\section{Case Study9}

A field experiment was conducted at Universiti Putra Malaysia Bintulu Sarawak Campus (latitude $03^{\circ} 21.516^{\prime} \mathrm{N}$ and longitude $\left.113^{\circ} 094.181^{\prime} \mathrm{E}\right)$. The climate is humid tropical with an annual precipitation of 4042 $\mathrm{mm}$, and the average monthly precipitation is $336.85 \mathrm{~mm}$, and the relative humidity is $85.6 \%$. The highest and the lowest temperatures are $32.1^{\circ} \mathrm{C}$ and $23.6^{\circ} \mathrm{C}$, respectively.
The test crop used was Zea mays L. F1 hybrid. Five seeds were sown in each planting hole and were thinned to one at seven days after seeding. The recommended rates of the fertilizers were: urea (130 $\left.\mathrm{kg} \mathrm{ha}^{-1}\right)$, Egypt rock phosphate (ERP) (214 $\left.\mathrm{kg} \mathrm{ha}^{-1}\right)$, Christmas Island rock phosphate (CIRP) (200 $\left.\mathrm{kg} \mathrm{ha}^{1}\right)$, triple superphosphate (TSP) $(130 \mathrm{~kg}$ $\left.\mathrm{ha}^{-1}\right)$, and muriate of potash (MOP) $\left(67 \mathrm{~kg} \mathrm{ha}^{-}\right.$ $\left.{ }^{1}\right)$. These rates were reduced to per plant basis and were equivalent to $4.85 \mathrm{~g}$ urea plant $^{-1}$, 7.95 g ERP plant $^{-1}, 7.42$ g CIRP plant $^{-1}, 4.84$ g TSP plant ${ }^{-1}$, and $2.47 \mathrm{~g} \mathrm{MOP} \mathrm{plant}^{-1}$ from the existing standard fertilizer recommendation. Half the fertilizer was applied at 10 days after seeding (DAS) and the remainder at 28 DAS. This method of fertilization was used to determine the maize plants' response to treatments. Weeding was done manually with hoe to keep the plots free from weeds.

From the table it was found that relative to control, significant $\mathrm{P}$ availability is noted in all $\mathrm{P}$ fertilizer treatments regardless of the rate and type of $\mathrm{P}$ fertilizer applied. The addition of $\mathrm{CZ}$ to the treatments with $75 \%$ fertilizers rate (T2, E2, and $\mathrm{C} 2$ ) showed comparable total $\mathrm{P}$ and available $\mathrm{P}$ with the recommended rate in both the first and second planting cycles. Inclusion of $\mathrm{CZ}$ in these treatments mitigated soil $\mathrm{pH}$ besides reducing $\mathrm{Al}$, and soil acidity. Hence, resulting in lesser amount of $\mathrm{P}$ being fixed to the soil colloid and metal ion oxyhydroxides. Although lesser amounts of $\mathrm{P}$ fertilizers were applied. Moreover, the comparable soil total $\mathrm{P}$, exchangeable $\mathrm{P}$, and soil exchangeable $\mathrm{Ca}$ contents obtained was possible due to enhanced dissolution of the PRs as affected by induce-exchange mechanism of the $\mathrm{CZ}$ mediated by maize plant uptake.(Hasbullah et al., 2018)

\section{Case Study10}

A field study was carried out at the Share 
Farm of Universiti Putra Malaysia Bintulu Sarawak Campus, Malaysia (latitude $3^{\circ} 30^{\prime} \mathrm{N}$, longitude $\left.113^{\circ} 09^{\prime} \mathrm{E}\right)$. The study area is a humid tropic with yearly average of low and high temperatures of $23^{\circ} \mathrm{C}$ and $34^{\circ} \mathrm{C}$, respectively. A field study was carried out from 10th April 2014 to 21st June 2014 for first planting cycle and 25th Juneto 27th August 2014 for second planting cycle of Zea mays L. These planting periods were considered short term because compost and clinoptilolite zeolite were applied before planting. Long-term effects involve repeated or regular application of amendments for many years. The experimental plots were arranged in a randomized complete block design (RCBD) with three blocks (replications). Thai Super Sweet hybrid F1 variety was used as the test crop.

Plots with chemical fertilizers, rice straw compost, and clinoptilolite zeolite (T2, T3, and T4) showed higher contents and uptake of $\mathrm{P}$ than the plots without fertilizer (T0) and chemical fertilizers (T1). Timely retention of available $\mathrm{P}$ might have enhanced the Zea mays L. growth and development. Coapplication of rice straw compost and chemical fertilizers increased soil microbial biomass $\mathrm{C}$ and activity and resulted in increased availability of P. Confirmed that soil available $\mathrm{P}$ following compost application contributes to $\mathrm{P}$ uptake. As observed in this study, amending compound fertilizers with clinoptilolite zeolite is also important because the approach ensures retention of soil $\mathrm{N}, \mathrm{P}, \mathrm{K}$, $\mathrm{Ca}$, and $\mathrm{Mg}$ to sustain vegetative growth until reproductive and kernel development of Zea mays L.

\section{Organic manure handling and management}

Zeolites could be used as an effective additive to control the odour (Sharadeqah and $\mathrm{Al}$ Dwairi, 2010), as they could adsorb the volatile substances (Rodriguez et al., 1994) like acetic acid, butanoic acid, isovalericacid,indole, skatole (Caiet al., 2007) and enhances effectiveness of the manure (Leggo, 2000). Surface application of zeolite has potential for mitigating farmyard manure $\mathrm{NH} 3$ losses thereby reducing losses of nitrogen to the environment, but specific zeolite properties influenced its effectiveness (Waldripet al., 2014). Nitrifying bacteria could not use the manure- ammonia in the zeolite due to small pore size (Mumpton, 1999). Ramesh and Islam (2012) have found reduced loss of ammonium from zeolite mixed with cow manure at Ohio, USA. Mature compost with good agronomic properties was produced by co-composting chicken slurry and paddy husk using zeolite and urea as additives by Latifahet al., (2015).

\section{Slow release of herbicides}

The most hydrophobic solidssuch as zeolite 'ZSM 5' were found to adsorb atrazine betterwhen organics were present (Botteroet al., 1994) in thecompartmentalized intracrystalline void space of zeolites(Corma and Garcia, 2004). This was brought a considerableattention on soil clay minerals for slow-release formulationof herbicides. Zeolite (ZSM-5) was found to accommodateherbicide paraquat in the microstructure with restrictedmobility (Walcarius and Mouchotte, 2004).This wasfollowed by surface modification of paraquat by Zhang etal.,(2006). Humic acid zeolites were also found to besorbents for phenylurea herbicides (Capassoet al., 2007).Clinoptilolitic tuff was considered as a suitable material forremoving atrazine from soil (Salvestrineet al., 2010) andwater (Jamilet al., 2011) too. Later an enhanced activity ofzeolite- loaded catalysts on herbicide isoproturon was foundto be synergistic effect of increased visible light absorptionand the high porous nature of zeolite facilitating theadsorption of 
recalcitrant molecules (Reddy et al., 2012).This was followed by Bakhiaryet al., (2013) with 2,4-Dherbicide showed gradual temporal release pattern and keptthe active ingredient in the upper $5 \mathrm{~cm}$ soil layer (Shirvaniet al., 2014).

\section{Slow release of nutrient}

Zeolite as coating material has shown the potential to increase water absorption and water retention of NPK fertilizers and to retard N,P and $\mathrm{K}$ release from the fertilizers in a sandy soil in Indonesia (Sulakhudin and Sunarminto, 2011).

\section{Case Study 11}

A laboratory study was undertaken at the Department of Nano Science \& Technology, Tamil Nadu Agricultural University, Coimbatore. During the experimentation, synthesis, characterization, $\mathrm{Zn}$ release pattern and $\mathrm{Zn}$ fractionation pattern were studied in nano-size zeolite fortified with or without $\mathrm{Zn}$.

Nano-zeolite showed leaching of $\mathrm{Zn}$ in three stages (Figure 9). Zn levels decrease sharply in the first $220 \mathrm{hr}$ and stabilize thereafter. The result also showed that from 300 to $500 \mathrm{hr}$ it follows second stage. In this stage, it supplies $1.5 \mathrm{ppm}$ of $\mathrm{Zn}$. The next stage falls from 500 $\mathrm{hr}$ and it supplies $1.1 \mathrm{ppm}$ of $\mathrm{Zn}$ and this condition is static even after 1,000 hr. This may be due to the fact that, the zeolite not only increases nutrient retention but also achieves the slow release process of nutrient for gradually releasing the nutrient to the plant so as to reduce environmental nutrient losses of the soil by means of the ion exchange ability. Therefore, the natural environmental materials of the diatomite and the zeolite are mixed was the plant growth medium for agriculture to increase crop yields. The data suggest that the nano-zeolite based fertilizers supply $\mathrm{Zn}$ for an extended period of up to 40 days, while such release ceased to exist within 10-12 days. The trend of $\mathrm{Zn}$ release pattern can be exploited in the development of nano-fertilizer that ensures sustainable plant development besides environmental safety.(Yuvaraj and Subramanian, 2018)

\section{Soil microbial properties}

In this trial four treatments with four replicates eachwere set up in a randomized, complete block design.The minimum experimental unit was a plot of $28 \mathrm{~m} 2$,divided into two equal subplots. In one of these, samplingsof soil and plants were made throughout thegrowing season, while the other was reserved for thefinal harvest. The treatments tested and doses appliedto the soil were: 1) the MC treatment was a basal dressingwith manure compost at a dose of 38 t ha-1; 2) theMCZ treatment was identical to $\mathrm{MC}$, but also zeolitewas simultaneously applied at a dose of $90 \mathrm{t}$ ha-1 (3\%);3) the MF treatment was a conventional mineral fertilization,serving as an assay control, and consisted of abasal dressing using an NPK complex (8-24-8) whichwas added to the soil at the recommended dose $(0.35$ tha- 1$)$ for the barley crop; 4) the ZL treatment consistedof a basal dressing with zeolite supplemented withleonardite at a dose of $75 \mathrm{t}$ ha-1. The topdressing dosewas divided into two halves, applying the first in thetillering phase of barley and the second in the stem extensionstage. The top-dressing dose applied was 90 Nfertilizer units (NFU), using calcium and ammoniumnitrate (27\%). The topdressing dose of the tested organictreatments (MC, MCZ, and ZL) was equivalentto a quarter of that applied in the conventional mineraltreatment (MF).

In general a decrease in soil enzyme activity,except for soil urease activity (URA), was observedduring the barley cultivation, 
regardlessof the basal dressing used (Figure $3)$. Forsoil $\beta$-glucosidase activity (BGA), significantdifferences were not observed between treatments. Soil alkaline phosphatase activity(APA) showed significant differences betweenthe treatment involving amendment with compostand that involving compost supplementedwith zeolite, being higher in the former. While the cellobiohydrolase activity $(\mathrm{CBH})$ was found significantlyhigher in treatments $\mathrm{MC}$ and $\mathrm{MCZ}$ thanin MF and ZL respectively. Similar values of ureaseactivity (URA) were measured in MC, MCZ, and MF during the barley cultivation, being significantlyhigher than that of ZL.(José Luise et al., 2017)

\section{Plant Yield and Yield Attributing Characteristic}

\section{Case Study 12}

An experiment was carried out at Share Farm ofUniversity Putra Malaysia of Bintulu Campus, Sarawak in Maize plant with organic, inorganic and Zeolites, where soil chemical properties were studied.

The Highest Cob weight ( $\mathrm{kg} / \mathrm{ha})$ and Grain/cob was observed in T4 (Table 13) as compared to the other treatment and which was significantly at par with Treatment $\mathrm{T} 1$, $\mathrm{T} 2$ and $\mathrm{T} 3$ but significantly different with $\mathrm{T} 0$. This Might be due to the incorporation of Zeolite along with compost manure.(Ahmed et al., 2010)

\section{Case Study13}

The experiment was plotted in the sugarcane growing areas of the northern coast of Villa Clara province. Different zeolite levels and combinations with organic fertilizers were applied in Vertisols (Table 14). The Experiment was set up as a randomized complete block design with 9 treatments and 4 replications. The individual plot sizes were $10 \times 9.6 \mathrm{~m}$. Sugarcane variety Ja $60-5$ was used and was planted in furrows at $1.60 \mathrm{~m}$ row spacing. Organic fertilizer (sugarcane filter cake-SFC), and natural mineral (zeolite$\mathrm{Z}$ ) and chemical fertilization (nitrogenphosphorus-potassium-NPK) were applied. The treatments were: T1- control (without application of fertilizer), T2- Z $7.5 \mathrm{t} \mathrm{ha}^{-1}$, T3Z $15 \mathrm{t} \mathrm{ha}^{-1}$, T4- Z $7.5 \mathrm{t} \mathrm{ha}^{-1}+100 \mathrm{~kg} \mathrm{ha}^{-1}$, T5$\mathrm{Z} 15 \mathrm{tha}^{-1}+\mathrm{N} 100 \mathrm{~kg} \mathrm{ha}^{-1}$, T6- Z $7.5 \mathrm{t} \mathrm{ha}^{-1}+$ SFC $22.5 \mathrm{t} \mathrm{ha}^{-1,}$ T7- Z $3 \mathrm{t} \mathrm{ha}^{-1}+$ SFC $18 \mathrm{tha}^{-1}$, T8- Z $7.5 \mathrm{t} \mathrm{ha}^{-1}+$ NPK (100-60-200 kg ha $\left.{ }^{-1}\right)$, T9- Z $7.5 \mathrm{t} \mathrm{ha}^{-1}+$ NPK (100-60-200 kg ha ${ }^{1}$ ).Significant effects on organic matter and structure were observed. Treatment, Z $7.5 \mathrm{t}$ $\mathrm{ha}^{-1}+$ SFC $22.5 \mathrm{t} \mathrm{ha}^{-1}$ (T6) showed the best result, where 3 of the indicators (organic matter, water-stable aggregates and degree of soil aggregation) reached the highest values. (Pedro Cairo, 2017)

Crop yield considered in these studies, had an extraordinary value for selecting quality indicators and determining soil quality. Hence, integration of natural minerals and organic amendments is suitable for Vertisols with high clay contents and improves physical soil properties. Application of Zeolite along with organic manure helps in improving cane yield and cane sucrose yield. The highest value observed in treatment $\mathbf{Z} 7.5 \mathrm{t} \mathrm{ha}^{-}$ ${ }^{1}+\mathbf{S F C}\left(22.5 \mathrm{t} \mathrm{ha}^{-1}\right)$ (table 14) as compared to other treatment and statistically found highly significant with other treatment.(Pedro Cairo, 2017)

\section{Wastewater treatment}

Zeolites may be used for removingammonia from wastewater. Clinoptilolite is effective for selective removal of $\mathrm{NH}_{4}+$ cations from wastewater. 
Table.1 Physical characteristics of some naturally occuring Zeolites (Dogan, 2003)

\begin{tabular}{|c|c|c|c|c|c|c|}
\hline Zeolite & $\begin{array}{c}\text { Porosity } \\
{[\%]}\end{array}$ & $\begin{array}{c}\text { Bulk density } \\
{\left[\mathbf{g} / \mathbf{c m}^{\mathbf{3}}\right]}\end{array}$ & $\begin{array}{c}\text { Ion } \\
\text { exchange } \\
\text { capacity } \\
{[\mathbf{m e q} / \mathbf{g}]}\end{array}$ & $\begin{array}{c}\text { Specific } \\
\text { gravity } \\
{\left[\mathbf{g} / \mathbf{c m}^{\mathbf{3}}\right]}\end{array}$ & $\begin{array}{c}\text { Heat } \\
\text { stability }\end{array}$ & Cations \\
\hline Analcime & 18 & 1.85 & 4.54 & $2.24-2.29$ & High & $\mathrm{Na}$ \\
\hline Chabezite & 47 & 1.45 & 3.84 & $2.05-2.10$ & High & $\mathrm{Ca}, \mathrm{Na}$ \\
\hline Clinoptilolite & 34 & 1.15 & 2.16 & $2.15-2.25$ & High & $\mathrm{Na}, \mathrm{K}, \mathrm{Ca}$ \\
\hline Erionite & 35 & 1.51 & 3.12 & $2.02-2.08$ & High & $\mathrm{K}, \mathrm{Na}, \mathrm{Ca}$ \\
\hline Heulandite & 39 & 1.69 & 2.91 & $2.18-2.20$ & Low & $\mathrm{Ca}$ \\
\hline Mordenite & 28 & 1.70 & 4.29 & $2.12-2.15$ & High & $\mathrm{Na}, \mathrm{Ca}$ \\
\hline Philipsite & 31 & 1.58 & 3.31 & $2.15-2.20$ & Moderate & $\mathrm{K}, \mathrm{Na}$ \\
\hline
\end{tabular}

Table.2 Natural Zeolites - Typical formulae of some zeolites (chemical composition)

\begin{tabular}{|l|l|l|}
\hline Zeolite & Typical Unit-Cell Formula & Cations \\
\hline Analcime & $\mathrm{Na}_{16}\left(\mathrm{Al}_{16} \mathrm{Si}_{32} \mathrm{O}_{96}\right) \cdot 16 \mathrm{H}_{2} \mathrm{O}$ & $\mathrm{Na}$ \\
\hline Chabazite & $\left(\mathrm{Na}_{2} \mathrm{Ca}_{6}\left(\mathrm{Al}_{12} \mathrm{Si}_{24} \mathrm{O}_{72}\right) \cdot 40 \mathrm{H}_{2} \mathrm{O}\right.$ & $\mathrm{Ca}, \mathrm{Na}$ \\
\hline Clinoptilolite & $\left(\mathrm{Na}_{4} \mathrm{~K}_{4}\right)\left(\mathrm{Al}_{8} \mathrm{Si}_{40} \mathrm{O}_{96}\right) \cdot 24 \mathrm{H}_{2} \mathrm{O}$ & $\mathrm{Na}, \mathrm{K}, \mathrm{Ca}$ \\
\hline Erionite & $\left(\mathrm{Na}_{2} \mathrm{Ca}_{6} \mathrm{~K}_{9}\left(\mathrm{Al}_{9} \mathrm{Si}_{27} \mathrm{O}_{27}\right) \cdot 27 \mathrm{H}_{2} \mathrm{O}\right.$ & $\mathrm{K}, \mathrm{Na}, \mathrm{Ca}$ \\
\hline Heulandite & $\mathrm{Ca}_{4}\left(\mathrm{Al}_{8} \mathrm{Si}_{28} \mathrm{O}_{72}\right) \cdot 24 \mathrm{H}_{2} \mathrm{O}$ & $\mathrm{Ca}$ \\
\hline Mordenite & $\mathrm{Na}_{8}\left(\mathrm{Al}_{8} \mathrm{Si}_{40} \mathrm{O}_{96}\right) \cdot 24 \mathrm{H}_{2} \mathrm{O}$ & $\mathrm{Na}, \mathrm{Ca}$ \\
\hline Phillipsite & $\left(\mathrm{Na}_{2} \mathrm{~K}\right)_{10}\left(\mathrm{Al}_{10} \mathrm{Si}_{22} \mathrm{O}_{62}\right) \cdot 20 \mathrm{H}_{2} \mathrm{O}$ & $\mathrm{K}, \mathrm{Na}$ \\
\hline
\end{tabular}

Table.3 Influence of zeolite and sugarcane filter cake on organic matter, soil aggregate and

\begin{tabular}{|c|c|c|c|c|c|}
\hline Sl. No. & Treatments & OM\% & WSA \% & DSA \% & $\log 10 k$ \\
\hline 1 & Control & $2.29 \mathrm{~g}$ & $64.18 \mathrm{e}$ & $54.03 \mathrm{e}$ & $1.84 \mathrm{f}$ \\
\hline 2 & Z 7.5 t ha-1 & $3.43 \mathrm{~cd}$ & $68.58 \mathrm{~d}$ & $57.24 \mathrm{~d}$ & $2.01 \mathrm{de}$ \\
\hline 3 & Z 15 t ha-1 & $3.57 \mathrm{~b}$ & $69.38 c$ & $60.65 c$ & $2.05 \mathrm{c}$ \\
\hline 4 & Z 7.5 t ha-1+ N(100 kg ha-1) & $3.46 \mathrm{c}$ & $68.58 \mathrm{~d}$ & $57.24 \mathrm{~d}$ & $2.13 \mathrm{a}$ \\
\hline 5 & Z 15 t ha-1+ N(100 kg ha-1) & $3.52 \mathrm{~b}$ & $69.38 \mathrm{c}$ & $60.65 c$ & $2.05 \mathrm{c}$ \\
\hline 6 & Z $7.5 \mathrm{t}$ ha- $1+\operatorname{SFC}(22.5 \mathrm{t}$ ha- 1$)$ & $3.71 \mathrm{a}$ & $71.04 \mathrm{a}$ & $65.57 \mathrm{a}$ & $2.09 \mathrm{~b}$ \\
\hline 7 & Z 3 t ha-1+SFC(18 t ha-1) & $3.40 \mathrm{de}$ & $69.67 \mathrm{~b}$ & $62.62 \mathrm{~b}$ & $2.14 \mathrm{a}$ \\
\hline 8 & $\begin{array}{l}Z 7.5 \text { t ha-1+NPK(100-60-200 kg ha- } \\
\text { 1) }\end{array}$ & $3.37 \mathrm{e}$ & $68.58 \mathrm{~d}$ & $57.24 \mathrm{~d}$ & $2.00 \mathrm{e}$ \\
\hline \multirow[t]{2}{*}{9} & Z $15 \mathrm{t} \mathrm{ha}^{-1}+\mathrm{NPK}\left(100-60-200 \mathrm{~kg} \mathrm{ha}^{-1}\right)$ & $3.24 \mathrm{f}$ & $69.38 \mathrm{c}$ & $60.65 \mathrm{c}$ & $2.04 \mathrm{~cd}$ \\
\hline & $\mathrm{EE}= \pm$ & 0.06 & 0.27 & 0.49 & 0.01 \\
\hline
\end{tabular}


Table.4 Effects of Clinoptilolite Zeolite along with other organic and inorganic fertilizers on selected chemical characteristics of soil at 72 days after planting of Maize

\begin{tabular}{|c|c|c|c|c|c|}
\hline Treatment & $\begin{array}{c}\mathbf{P}^{\mathbf{H}} \\
\text { Water }\end{array}$ & $\begin{array}{c}\text { Total } \mathbf{N} \\
(\%)\end{array}$ & $\begin{array}{l}\text { Available P } \\
\left(\mathrm{mg} \mathrm{kg}^{-1}\right)\end{array}$ & $\begin{array}{l}\text { Exchangeable } \\
\mathrm{K}^{+}\left(\mathrm{cmol} \mathrm{kg}^{-1}\right)\end{array}$ & $\begin{array}{c}\text { Exchangeable } \\
\mathrm{NH}_{4}^{+} \\
\left(\mathrm{mg} \mathrm{kg}^{-1}\right)\end{array}$ \\
\hline Soil only $\left(\mathbf{T}_{1}\right)$ & $\begin{array}{l}5.72^{\mathrm{b}} \\
\pm \\
0.26\end{array}$ & $\begin{array}{l}0.18^{b} \\
\pm 0.04\end{array}$ & $\begin{array}{l}0.004^{\mathrm{a}} \\
\pm 0.002\end{array}$ & $\begin{array}{l}5.96^{\mathrm{b}} \\
\pm 0.39\end{array}$ & $\begin{array}{l}47.60^{\mathrm{b}} \\
\pm 2.80\end{array}$ \\
\hline $\begin{array}{l}7.4 \mathrm{~g} \text { Urea }+5.0 \mathrm{~g} \mathrm{TSP}+3.8 \mathrm{~g} \\
\operatorname{MOP}\left(\mathrm{T}_{2}\right)\end{array}$ & $\begin{array}{l}5.82^{\mathrm{ab}} \\
\pm \\
0.11\end{array}$ & $\begin{array}{r}0.45^{\mathrm{a}} \\
\pm 0.03\end{array}$ & $\begin{aligned} & 0.003^{\mathrm{a}} \\
\pm & 0.0003\end{aligned}$ & $\begin{array}{l}10.07^{\mathrm{a}} \\
\pm 0.64\end{array}$ & $\begin{array}{l}534.67^{\mathrm{a}} \\
\pm 43.47\end{array}$ \\
\hline $\begin{array}{l}7.4 \mathrm{~g} \text { Urea }+5.0 \mathrm{~g} \text { TSP }+3.8 \mathrm{~g} \\
\text { MOP }+192 \mathrm{~g} \text { Clinoptilolite }\left(\mathrm{T}_{3}\right)\end{array}$ & $\begin{array}{l}6.22^{\mathrm{ab}} \\
\pm \\
0.148\end{array}$ & $\begin{array}{r}0.39^{\mathrm{a}} \\
\pm 0.04\end{array}$ & $\begin{array}{r}0.002^{\mathrm{a}} \\
\pm 0.001\end{array}$ & $\begin{array}{l}11.89^{\mathrm{a}} \\
\pm 0.44\end{array}$ & $\begin{array}{l}709.33^{\mathrm{a}} \\
\pm 18.67\end{array}$ \\
\hline $\begin{array}{l}\text { 5.55g Urea + } 3.75 \text { g TSP + } 2.85 \\
\text { g MOP + } 192 \text { g Clinoptilolite + } \\
192 \text { g Compost }\left(\mathrm{T}_{4}\right)\end{array}$ & $\begin{array}{l}6.48^{\mathrm{a}} \\
\pm \\
0.15\end{array}$ & $\begin{array}{r}0.41^{\mathrm{a}} \\
\pm 0.02\end{array}$ & $\begin{array}{r}0.002^{\mathrm{a}} \\
\pm 0.001\end{array}$ & $\begin{array}{l}11.77^{\mathrm{a}} \\
\pm 0.14\end{array}$ & $\begin{array}{l}601.33^{\mathrm{a}} \\
\pm 45.63\end{array}$ \\
\hline $\begin{array}{l}3.70 \text { g urea }+2.50 \text { g TSP }+1.90 \\
\text { g MOP + } 192 \text { g Clinoptilolite } \\
\text { Zeolite }+385 \text { g Compost }\left(\mathrm{T}_{5}\right)\end{array}$ & $\begin{array}{l}6.15^{\mathrm{ab}} \\
\pm \\
0.08\end{array}$ & $\begin{array}{c}0.44^{\mathrm{a}} \\
\pm 0.03\end{array}$ & $\begin{array}{r}0.004^{\mathrm{a}} \\
\pm 0.002\end{array}$ & $\begin{array}{l}11.05^{\mathrm{a}} \\
\pm 0.75\end{array}$ & $\begin{array}{l}624.00^{\mathrm{a}} \\
\pm 48.00\end{array}$ \\
\hline
\end{tabular}

Table.5 Mean comparison of interaction effects of fertilizer treatments on DMY of Sunflower, IWP and CEC of soil

\begin{tabular}{|c|c|c|c|c|}
\hline Year & Fertilizer treatments & $\begin{array}{l}\text { Dry matter } \\
\text { yield } \\
\text { Sunflower } \\
\left(\text { kg ha }^{1}\right)\end{array}$ & $\begin{array}{l}\text { Irrigation } \\
\text { Water } \\
\text { Productivity } \\
\left(\mathrm{kg} \mathrm{m}^{3}\right)\end{array}$ & $\begin{array}{l}\text { Cation } \\
\text { exchange } \\
\text { capacity ) } \\
\left(\text { meq } 100 \mathrm{~g} \text { soil }^{1}\right)\end{array}$ \\
\hline \multirow{5}{*}{$\begin{array}{l}2008- \\
2009\end{array}$} & $\mathrm{~F} 1: 130 \mathrm{~kg} / \mathrm{ha} \mathrm{N}$ as urea & $4660 \mathrm{~d}$ & $0.50 \mathrm{c}$ & $7.0 \mathrm{c}$ \\
\hline & $\begin{array}{l}\mathrm{F} 2: 80 \mathrm{~kg} / \mathrm{ha} \mathrm{N} \text { as urea }+50 \mathrm{~kg} / \mathrm{ha} \mathrm{N} \\
\text { as cattle manure }\end{array}$ & $5040 \mathrm{c}$ & $0.53 \mathrm{bc}$ & $8.2 \mathrm{~b}$ \\
\hline & $\begin{array}{l}\text { F3: } 80 \mathrm{~kg} / \mathrm{ha} \mathrm{N} \text { as urea }+50 \mathrm{~kg} / \mathrm{ha} \mathrm{N} \\
\text { as cattle manure plus } 7 \% \text { zeolite, }\end{array}$ & $4980 \mathrm{c}$ & $0.55 \mathrm{ab}$ & $8.2 \mathrm{~b}$ \\
\hline & $\begin{array}{l}\mathrm{F} 4: 80 \mathrm{~kg} / \mathrm{ha} \mathrm{N} \text { as urea }+50 \mathrm{~kg} / \mathrm{ha} \mathrm{N} \\
\text { as cattle manure plus } 14 \% \text { zeolite }\end{array}$ & $5520 \mathrm{~b}$ & $0.55 \mathrm{ab}$ & $8.4 \mathrm{ab}$ \\
\hline & $\begin{array}{l}\mathrm{F} 5: 80 \mathrm{~kg} \text { /ha } \mathrm{N} \text { as urea }+50 \mathrm{~kg} / \mathrm{ha} \mathrm{N} \\
\text { as cattle manure plus } 21 \% \text { zeolite }\end{array}$ & $5830 \mathrm{a}$ & $0.57 \mathrm{a}$ & $8.7 \mathrm{a}$ \\
\hline
\end{tabular}


Table.6 Soilcation exchange capacity and $\mathrm{pH}$ at $72 \mathrm{DAS}$ of Maize

\begin{tabular}{|c|c|c|}
\hline Treatment & CEC $\left(\mathrm{cmol}_{\mathrm{c}} \mathrm{kg}^{-1}\right)$ (S.E.) & pH (S.E.) \\
\hline \multicolumn{3}{|l|}{ First cycle } \\
\hline $\mathbf{T}_{\mathbf{0}}$ & $7.92^{\mathrm{d}}(0.32)$ & $4.25^{\mathrm{c}}(0.14)$ \\
\hline$T_{1}$ & $18.02^{\mathrm{c}}(0.42)$ & $5.68^{\mathrm{b}}(0.08)$ \\
\hline $\mathbf{T}_{2}$ & $22.55^{\mathrm{b}}(0.66)$ & $6.22^{\mathrm{a}}(0.14$ \\
\hline $\mathbf{T}_{3}$ & $26.14^{\mathrm{a}}(0.47)$ & $6.48^{\mathrm{a}}(0.14)$ \\
\hline $\mathbf{T}_{4}$ & $24.15^{\mathrm{ab}}(0.60)$ & $6.12^{\mathrm{ab}}(0.07)$ \\
\hline \multicolumn{3}{|l|}{ Second Cycle } \\
\hline$T_{0}$ & $7.35^{\mathrm{c}}(0.13)$ & $4.10^{\mathrm{c}}(0.08)$ \\
\hline$T_{1}$ & $17.42^{\mathrm{b}}(0.25)$ & $5.54^{\mathrm{b}}(0.14)$ \\
\hline $\mathbf{T}_{2}$ & $24.11^{\mathrm{a}}(0.34)$ & $6.31^{\mathrm{a}}(0.14)$ \\
\hline $\mathbf{T}_{3}$ & $25.81^{\mathrm{a}}(0.55)$ & $6.43^{\mathrm{a}}(0.14)$ \\
\hline $\mathbf{T}_{4}$ & $24.22^{\mathrm{a}}(0.44)$ & $6.46^{\mathrm{a}}(0.07)$ \\
\hline
\end{tabular}

Table.7 Effects of Clinoptilolitesalongwith other organic and inorganic fertilizer treatments on Nutrient uptake in maize plant

\begin{tabular}{|c|c|c|c|}
\hline \multirow[t]{2}{*}{ Treatment } & \multicolumn{3}{|c|}{ Total Uptake, (g plant $\left.{ }^{-1}\right)$} \\
\hline & $\mathbf{N}$ & $\mathbf{P}$ & $\mathbf{K}$ \\
\hline$T_{0}$ : Soil only & $0.11^{\mathrm{b}} \pm 5.41$ & $0.03^{\mathrm{d}} \pm 1.44$ & $0.05^{\mathrm{b}} \pm 2.77$ \\
\hline $\mathrm{T}_{1}: 7.4 \mathrm{~g}$ Urea + 5.0 g TSP + 3.8 g MOP & $1.77^{\mathrm{a}} \pm 22.31$ & $0.67^{c} \pm 3.45$ & $1.76^{\mathrm{a}} \pm 10$ \\
\hline $\begin{array}{l}T_{2}: 7.4 \text { g Urea + 5.0 g TSP + 3.8 g MOP + } \\
192 \text { g Clinoptilolite }\end{array}$ & $2.06^{\mathrm{a}} \pm 7.36$ & $1.01^{\mathrm{ab}} \pm 2.22$ & $2.05^{\mathrm{a}} \pm 3.58$ \\
\hline $\begin{array}{l}\mathrm{T}_{3}: 5.55 \mathrm{~g} \text { Urea }+3.75 \mathrm{~g} \text { TSP }+2.85 \mathrm{~g} \text { MOP } \\
+192 \mathrm{~g} \text { Clinoptilolite }+192 \mathrm{~g} \text { Compost }\end{array}$ & $2.17^{\mathrm{a}} \pm 22.02$ & $0.92^{\mathrm{b}} \pm 4.42$ & $2.09^{\mathrm{a}} \pm 6.34$ \\
\hline $\begin{array}{l}\mathrm{T}_{4}: 3.70 \mathrm{~g} \text { urea }+2.50 \mathrm{~g} \text { TSP }+1.90 \mathrm{~g} \text { MOP } \\
+192 \mathrm{~g}+\text { Clinoptilolite }+385 \mathrm{~g} \text { Compost }\end{array}$ & $2.18^{\mathrm{a}} \pm 15.79$ & $1.17^{\mathrm{a}} \pm 7.86$ & $2.13^{\mathrm{a}} \pm 9.49$ \\
\hline
\end{tabular}

Table.8 Mean comparison of interaction effects of fertilizer treatments on Nitrogen leaching

\begin{tabular}{|c|c|c|}
\hline $\begin{array}{l}\text { Irrigation } \\
\text { regimes }\end{array}$ & Fertilizer treatments & $\begin{array}{l}\text { N.L }(\mathbf{k g} \\
\left.\text { ha }^{1}\right)\end{array}$ \\
\hline \multirow{5}{*}{$\begin{array}{l}2008 \text { (Full } \\
\text { Irrigation) }\end{array}$} & $\mathrm{F} 1: 130 \mathrm{~kg} / \mathrm{ha} \mathrm{N}$ as urea & 36 a \\
\hline & $\begin{array}{l}\mathrm{F} 2: 80 \mathrm{~kg} / \mathrm{ha} \mathrm{N} \text { as urea }+50 \mathrm{~kg} / \mathrm{ha} \mathrm{N} \\
\text { as cattle manure }\end{array}$ & $31 \mathrm{~b}$ \\
\hline & F3F3: $80 \mathrm{~kg}$ /ha N as urea $+50 \mathrm{~kg} /$ ha $\mathrm{N}$ as cattle manure plus $7 \%$ zeolite, & $28 \mathrm{bc}$ \\
\hline & $80 \mathrm{~kg} / \mathrm{ha} \mathrm{N}$ as urea $+50 \mathrm{~kg} / \mathrm{ha} \mathrm{N}$ as cattle manure plus $14 \%$ zeolite & $25 \mathrm{~cd}$ \\
\hline & F5:80 kg /ha $\mathrm{N}$ as urea $+50 \mathrm{~kg} / \mathrm{ha} \mathrm{N}$ as cattle manure plus $21 \%$ zeolite & $22 \mathrm{~d}$ \\
\hline \multirow[t]{5}{*}{2009} & F1 & $15 \mathrm{a}$ \\
\hline & $\mathrm{F} 2$ & $13 \mathrm{a}$ \\
\hline & F3: & $14 \mathrm{a}$ \\
\hline & F4: & $11 \mathrm{a}$ \\
\hline & F5: & $10 \mathrm{a}$ \\
\hline
\end{tabular}


Table.9 Mean comparison of grain yield and total nitrogen in shoots of wheat plant

\begin{tabular}{|c|l|l|}
\hline Treatments & $\begin{array}{c}\text { Nitrogen in shoots } \\
(\mathbf{\%})\end{array}$ & $\begin{array}{c}\text { Grains yield } \\
(\mathbf{k g} / \mathbf{h a})\end{array}$ \\
\hline $\begin{array}{c}\text { Contrast } \\
\text { effect }\end{array}$ & & \\
\hline Clay loam & & \\
\hline $\mathbf{Z}_{\mathbf{0}}$ & $0.77 \mathrm{bc}$ & $3138 \mathrm{a}$ \\
\hline $\mathbf{Z}_{\mathbf{1}}$ & $0.72 \mathrm{c}$ & $2877 \mathrm{a}$ \\
\hline $\mathbf{Z}_{\mathbf{2}}$ & $0.69 \mathrm{c}$ & $2845 \mathrm{a}$ \\
\hline $\mathbf{Z}_{\mathbf{3}}$ & $0.77 \mathrm{bc}$ & $3092 \mathrm{a}$ \\
\hline $\mathbf{Z}_{\mathbf{4}}$ & $0.76 \mathrm{bc}$ & $3834 \mathrm{a}$ \\
\hline Sandy Loam & & \\
\hline $\mathbf{Z}_{\mathbf{0}}$ & $0.86 \mathrm{a}$ & $3517 \mathrm{a}$ \\
\hline $\mathbf{Z}_{\mathbf{1}}$ & $0.76 \mathrm{bc}$ & $3554 \mathrm{a}$ \\
\hline $\mathbf{Z}_{\mathbf{2}}$ & $0.74 \mathrm{c}$ & $3488 \mathrm{a}$ \\
\hline $\mathbf{Z}_{\mathbf{3}}$ & $0.75 \mathrm{c}$ & $3584 \mathrm{a}$ \\
\hline $\mathbf{Z}_{\mathbf{4}}$ & $0.83 \mathrm{ab}$ & $4225 \mathrm{a}$ \\
\hline Main effect & & \\
\hline $\mathbf{Z e o l i t e}$ & & \\
\hline $\mathbf{Z}_{\mathbf{0}}$ & $0.8 \mathrm{a}$ & $3328 \mathrm{~b}$ \\
\hline $\mathbf{Z}_{\mathbf{1}}$ & $0.74 \mathrm{bc}$ & $3338 \mathrm{~b}$ \\
\hline $\mathbf{Z}_{\mathbf{2}}$ & $0.72 \mathrm{c}$ & $3167 \mathrm{~b}$ \\
\hline $\mathbf{Z}_{\mathbf{3}}$ & $0.76 \mathrm{bc}$ & $3338 \mathrm{~b}$ \\
\hline $\mathbf{Z}_{\mathbf{4}}$ & $0.8 \mathrm{a}$ & $4030 \mathrm{a}$ \\
\hline Main effect & & \\
\hline Soil texture & & $3157 \mathrm{~b}$ \\
\hline Clay loam & $0.74 \mathrm{~b}$ & $3674 \mathrm{a}$ \\
\hline Sandy loam & $0.79 \mathrm{a}$ & \\
\hline
\end{tabular}

For a given means within each column of each section followed by the same letter are not significantly different ( $p \leq$ $0.05)$

Table.10 Treatment Details of the experiment

\begin{tabular}{|c|c|c|c|c|}
\hline \multirow{2}{*}{ Treatment } & Urea & P fertilizer & MOP & CZ \\
\cline { 2 - 5 } & \multicolumn{2}{|c|}{ (g/plant) } \\
\hline $\mathbf{T}_{\mathbf{0}}$ & 0 & 0 & 0 & 0 \\
\hline $\mathbf{T}_{\mathbf{1}}$ & 4.85 & 4.84 & 2.47 & 10.34 \\
\hline $\mathbf{T}_{\mathbf{2}}$ & 3.64 & 3.63 & 1.85 & \\
\hline $\mathbf{E}_{\mathbf{1}}$ & 4.85 & 7.95 & 2.47 & 13.00 \\
\hline $\mathbf{E}_{\mathbf{2}}$ & 3.64 & 5.96 & 1.85 & \\
\hline $\mathbf{C}_{\mathbf{1}}$ & 4.85 & 7.42 & 2.47 & 12.50 \\
\hline $\mathbf{C}_{\mathbf{2}}$ & 3.64 & 5.57 & 1.85 & \\
\hline
\end{tabular}


Table.11 Selected soil physical-chemical properties of soil after sowing of maize seeds

\begin{tabular}{|c|c|l|l|l|l|l|}
\hline Treatment & \multicolumn{2}{|c|}{ PH } & \multicolumn{2}{c|}{ Total P(ppm) } & \multicolumn{2}{c|}{ Available P (ppm) } \\
\hline & FC & SC & FC & SC & FC & SC \\
\hline $\mathbf{T}_{\mathbf{0}}$ & $4.43 \mathrm{c} \pm 0.01$ & $4.60 \mathrm{~b} \pm 0.10$ & $10.36 \mathrm{~b} \pm 0.46$ & $11.67 \pm 0.23$ & $4.95 \mathrm{~b} \pm 0.76$ & $4.17 \mathrm{c} \pm 0.07$ \\
\hline $\mathbf{T}_{\mathbf{1}}$ & $5.51 \mathrm{a} \pm 0.04$ & $5.21 \mathrm{a} \pm 0.05$ & $20.19 \mathrm{a} \pm 0.03$ & $21.85 \mathrm{a} \pm 1.95$ & $12.77 \mathrm{a} \pm 1.19$ & $13.62 \mathrm{a} \pm 0.26$ \\
\hline $\mathbf{T}_{\mathbf{2}}$ & $5.11 \mathrm{~b} \pm 0.03$ & $5.43 \mathrm{a} \pm 0.00$ & $21.19 \mathrm{a} \pm 1.61$ & $19.93 \mathrm{a} \pm 0.69$ & $7.08 \mathrm{a} \pm 0.65$ & $9.36 \mathrm{~b} \pm 1.31$ \\
\hline $\mathbf{E}_{\mathbf{1}}$ & $5.10 \mathrm{a} \pm 0.08$ & $5.55 \mathrm{a} \pm 0.02$ & $27.82 \mathrm{a} \pm 1.48$ & $22.53 \mathrm{a} \pm 0.44$ & $10.82 \mathrm{~b} \pm 0.48$ & $9.02 \mathrm{~b} \pm 0.26$ \\
\hline $\mathbf{E}_{\mathbf{2}}$ & $4.88 \mathrm{~b} \mathrm{a} \pm 0.12$ & $5.46 \mathrm{a} \pm 0.06$ & $30.17 \mathrm{a} \pm 1.26$ & $30.80 \mathrm{~b} \pm 0.30$ & $18.82 \mathrm{a} \pm 1.37$ & $11.58 \mathrm{a} \pm 0.78$ \\
\hline $\mathbf{C}_{\mathbf{1}}$ & $5.34 \mathrm{a} \pm 0.06$ & $5.39 \mathrm{a} \pm 0.05$ & $24.01 \mathrm{a} \pm 2.05$ & $25.75 \mathrm{a} \pm 0.01$ & $13.05 \mathrm{a} \pm 1.05$ & $12.03 \mathrm{a} \pm 1.46$ \\
\hline $\mathbf{C}_{\mathbf{2}}$ & $5.19 \mathrm{~b} \pm 0.01$ & $5.34 \mathrm{a} \pm 0.04$ & $26.20 \mathrm{a} \pm 0.62$ & $22.47 \mathrm{a} \pm 1.25$ & $11.72 \mathrm{a} \pm 1.36$ & $13.10 \mathrm{a} \pm 1.22$ \\
\hline
\end{tabular}

Table.12 Effect of treatments (T0, T1, T2, T3, and T4) on phosphorus uptake of Zea mays L. above ground biomass at 72 DAS

\begin{tabular}{|c|c|}
\hline Treatment & $\begin{array}{l}\text { P uptake (mg } \\
\left.\mathrm{kg}^{-1}\right) \text { Mean (S.E.) }\end{array}$ \\
\hline First cycle & \multirow[t]{2}{*}{$1046^{\mathrm{e}}( \pm 2.90)$} \\
\hline $\mathbf{T}_{0}$ : Soil only (control) & \\
\hline $\mathrm{T}_{1}: 7.40 \mathrm{~g}$ urea $+5 \mathrm{~g}$ TSP $+3.80 \mathrm{~g}$ MOP & $1534^{\mathrm{d}}( \pm 6.55)$ \\
\hline$T_{2}: 7.40$ g urea + 5 g TSP + 3.80 g MOP + 192 g clinoptilolite zeolite & $3553^{\mathrm{a}}( \pm 6.06)$ \\
\hline $\mathrm{T}_{3}: .55 \mathrm{~g}$ urea $+3.75 \mathrm{~g}$ TSP + $2.85 \mathrm{~g} \mathrm{MOP}+385 \mathrm{~g} \mathrm{C}+192 \mathrm{~g} \mathrm{CZ}$ & $3238^{\mathrm{b}}( \pm 9.90)$ \\
\hline $\mathrm{T}_{4}: 3.70 \mathrm{~g}$ urea $+2.50 \mathrm{~g}$ TSP $+1.90 \mathrm{~g}$ MOP $+577 \mathrm{~g} \mathrm{C}+192 \mathrm{~g} \mathrm{CZ}$ & $2340^{\mathrm{c}}( \pm 2.08)$ \\
\hline Second cycle & \multirow[t]{2}{*}{$1023^{\mathrm{e}}( \pm 5.78)$} \\
\hline $\mathbf{T}_{\mathbf{0}}$ & \\
\hline $\mathbf{T}_{1}$ & $1467^{\mathrm{d}}( \pm 2.72)$ \\
\hline $\mathbf{T}_{2}$ & $3448^{\mathrm{a}}( \pm 1.73)$ \\
\hline $\mathbf{T}_{3}$ & $3247^{\mathrm{b}}( \pm 1.76)$ \\
\hline $\mathbf{T}_{4}$ & $2427^{\mathrm{c}}( \pm 3.05)$ \\
\hline
\end{tabular}

Table.13 Effects of Inorganic, Organic and NZ treatments on maize Yield and Yield attributes

\begin{tabular}{|c|c|c|}
\hline Treatments & $\begin{array}{l}\text { Cob weight } \\
\text { (kg/ha) }\end{array}$ & Grain/ cob \\
\hline$T_{0}$ : Soil only & $1.5^{b} \pm 0.0003$ & $242.50^{b} \pm 4.5$ \\
\hline $\mathrm{T}_{1}: 7.4 \mathrm{~g}$ Urea $+5.0 \mathrm{~g} \mathrm{TSP}+3.8 \mathrm{~g}$ MOP & $6.6^{\mathrm{a}} \pm 0.0003$ & $648.00^{\mathrm{a}} \pm 15.59$ \\
\hline $\begin{array}{l}\mathrm{T}_{2}: 7.4 \mathrm{~g} \text { Urea }+5.0 \mathrm{~g} \text { TSP }+3.8 \mathrm{~g} \text { MOP }+ \\
192 \text { g Clinoptilolite }\end{array}$ & $6.4^{\mathrm{a}} \pm 0.0004$ & $657.33^{a} \pm 22.43$ \\
\hline $\begin{array}{l}\mathrm{T}_{3}: 5.55 \mathrm{~g} \text { Urea }+3.75 \mathrm{~g} \text { TSP }+2.85 \mathrm{~g} \text { MOP }+ \\
192 \text { g Clinoptilolite }+192 \mathrm{~g} \text { Compost }\end{array}$ & $6.5^{\mathrm{a}} \pm 0.0002$ & $681.67^{a} \pm 21.67$ \\
\hline $\begin{array}{l}\mathrm{T}_{4}: 3.70 \mathrm{~g} \text { urea }+2.50 \mathrm{~g} \text { TSP }+1.90 \mathrm{~g} \text { MOP } \\
+192 \mathrm{~g}+\text { +Clinoptilolite }+385 \mathrm{~g} \text { Compost }\end{array}$ & $6.6^{\mathrm{a}} \pm 0.0002$ & $709.00^{\mathrm{a}} \pm 8.02$ \\
\hline
\end{tabular}


Table.14 Influence of zeolite and sugarcane filter cake on sugarcane yield

\begin{tabular}{|c|c|c|}
\hline Treatments & $\begin{array}{l}\text { Cane yield } \\
\left(\mathrm{t} \mathrm{ha}^{-1}\right)\end{array}$ & $\begin{array}{l}\text { Sucrose yield } \\
\left(\mathrm{t} \mathrm{ha}^{-1}\right)\end{array}$ \\
\hline Control & $86.37 \mathrm{i}$ & $14.99 \mathrm{i}$ \\
\hline Z 7.5 t ha $^{-1}$ & $89.41 \mathrm{~h}$ & $15.31 \mathrm{~h}$ \\
\hline $\mathrm{Z} 15 \mathrm{t} \mathrm{ha}^{-1}$ & $114.40 \mathrm{f}$ & $19.48 \mathrm{f}$ \\
\hline Z $7.5 \mathrm{t} \mathrm{ha}^{-1}+\mathrm{N}\left(100 \mathrm{~kg} \mathrm{ha}^{-1}\right)$ & $154.84 \mathrm{~b}$ & $24.14 \mathrm{a}$ \\
\hline Z 15 t ha $^{-1}+\mathrm{N}\left(100 \mathrm{~kg} \mathrm{ha}^{-1}\right)$ & $142.30 \mathrm{c}$ & $23.84 \mathrm{c}$ \\
\hline Z $7.5 \mathrm{t} \mathrm{ha}^{-1}+\operatorname{SFC}\left(22.5 \mathrm{t} \mathrm{ha}^{-1}\right)$ & $162.00 \mathrm{a}$ & $24.42 \mathrm{~b}$ \\
\hline Z 3 t ha $^{-1}+\operatorname{SFC}\left(18\right.$ tha $\left.^{-1}\right)$ & $137.66 \mathrm{~d}$ & $22.95 \mathrm{~d}$ \\
\hline $\mathrm{Z} 7.5 \mathrm{t} \mathrm{ha}^{-1}+\mathrm{NPK}\left(100-60-200 \mathrm{~kg} \mathrm{ha}^{-1}\right)$ & $135.79 \mathrm{e}$ & $22.19 \mathrm{e}$ \\
\hline Z $15 \mathrm{t} \mathrm{ha}^{-1}+\mathrm{NPK}\left(100-60-200 \mathrm{~kg} \mathrm{ha}^{-1}\right)$ & $106.93 \mathrm{~g}$ & $17.29 \mathrm{~g}$ \\
\hline $\mathbf{E E}= \pm$ & 3.90 & 0.58 \\
\hline
\end{tabular}

Tukey HSD at $\mathrm{p} \leq 0.05$. SFC (sugarcane filter cake)

Fig.2 CEC mechanism of Zeolite

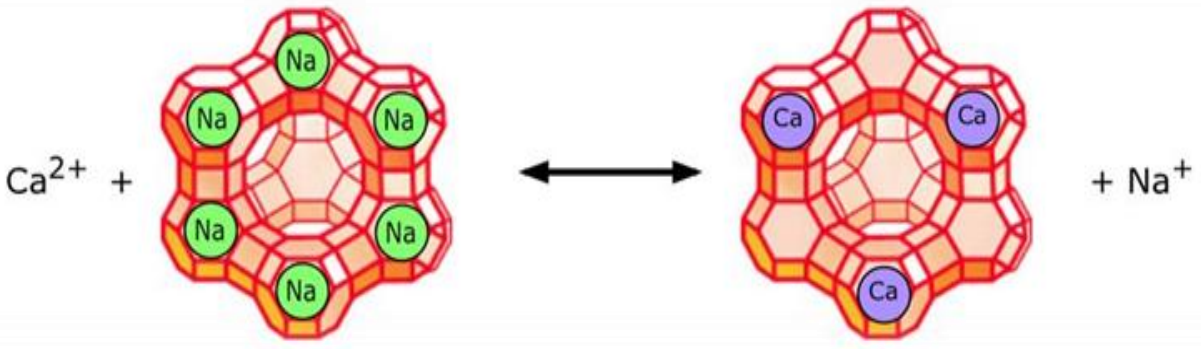

Fig.3 Adsorption and related molecular sieving mechanism of Zeolite

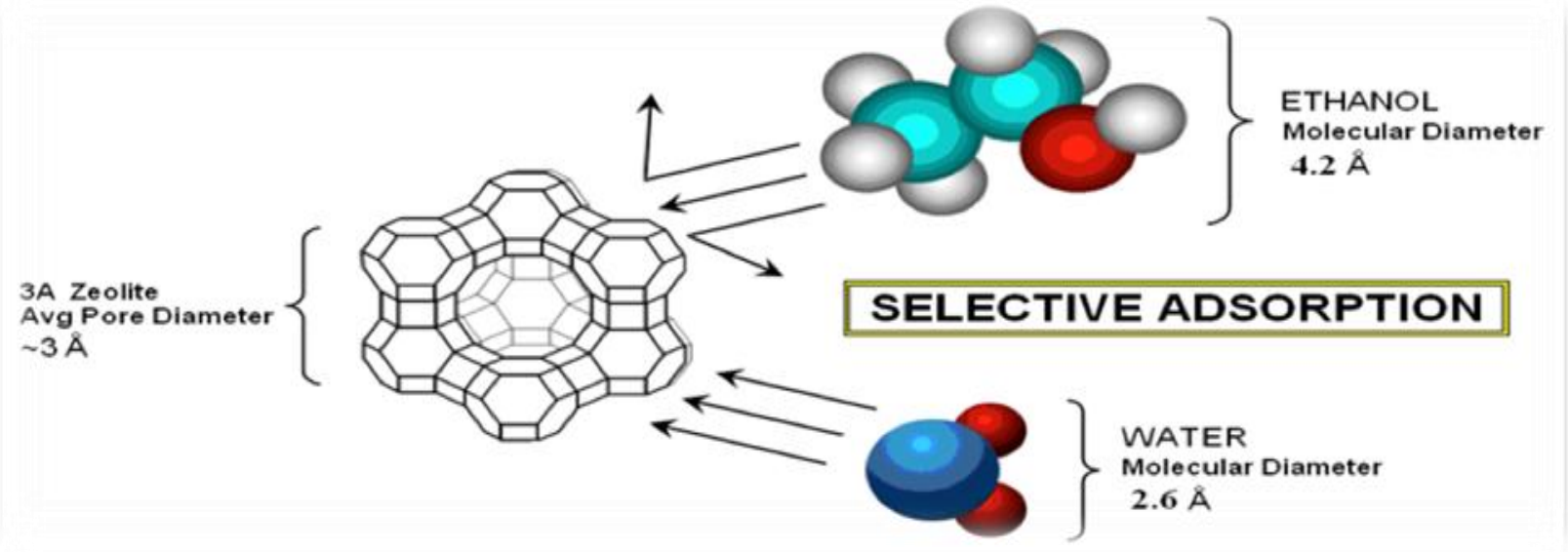


Fig.4 Rehydration and Dehydration mechanism of Zeolite

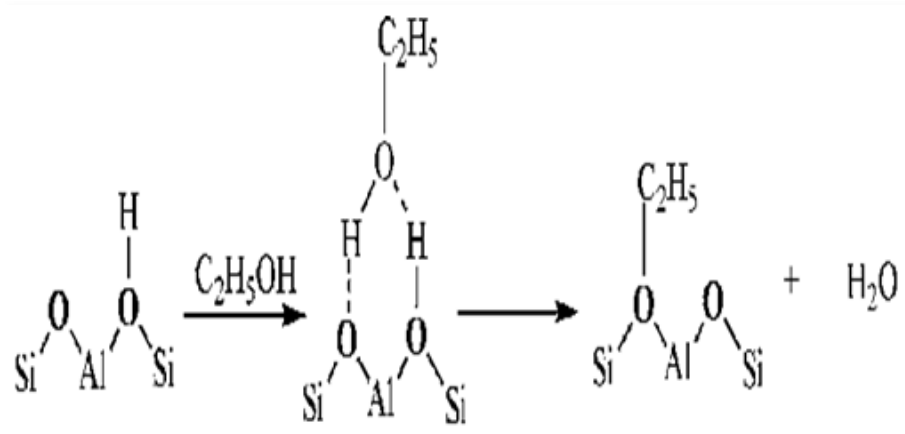

Fig.5 Natural zeolite formation

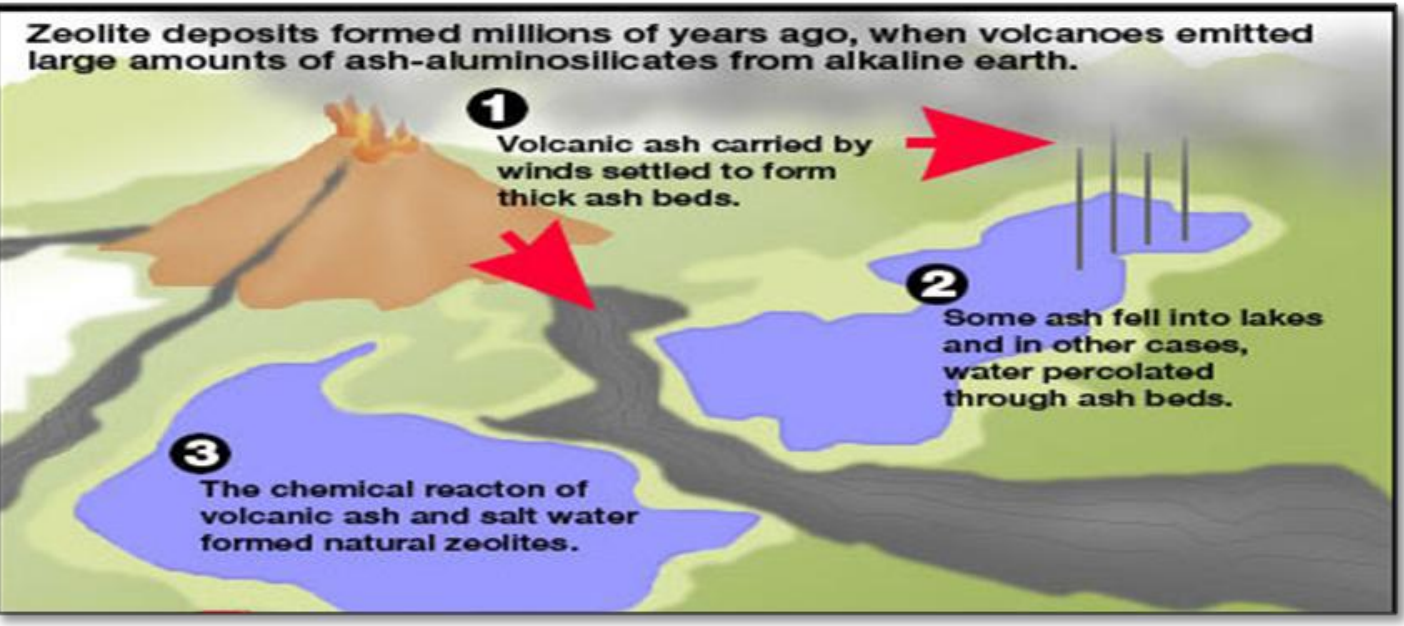

Fig.6 Soil moisture profile ( $25 \mathrm{~mm}$ of rain before sampling). Average values of sampling of the soil moisture content ( 7.5 tha $^{-1}+$ SFC $\left.22.5 \mathrm{tha}^{-1}\right)$ Average values of sampling of the soil moisture content (Control without fertilization)

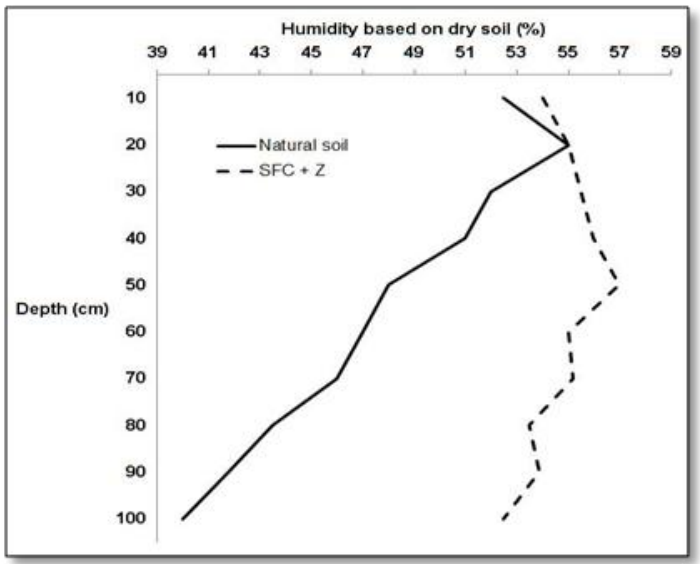


Fig.7\& 8: Oragnic carbon of soil First Cycle and Second Cycle respectively

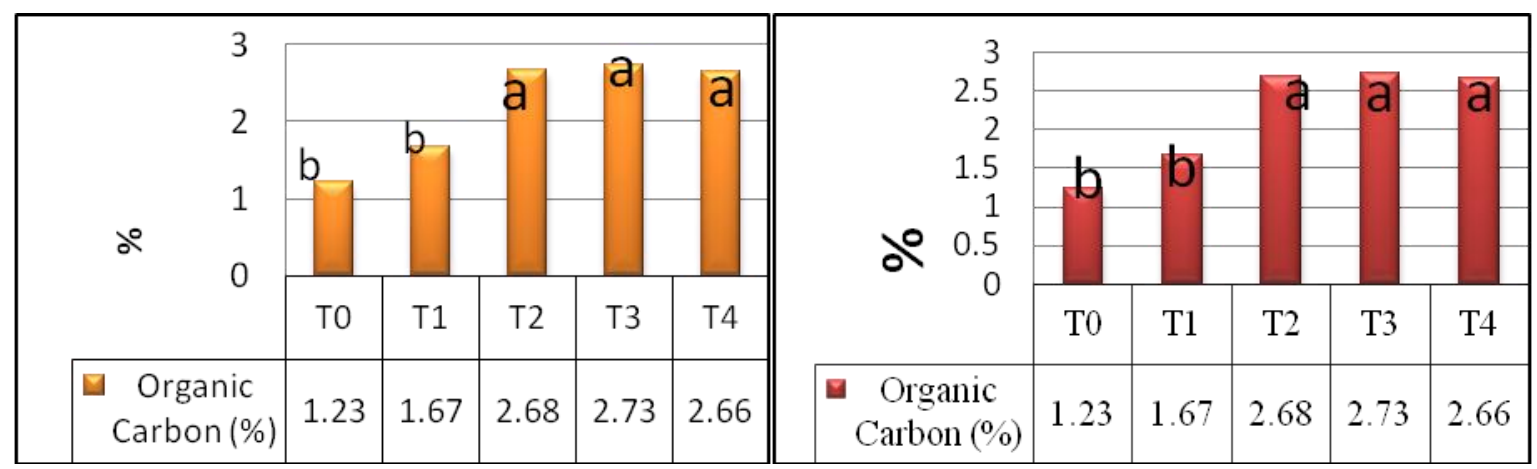

Fig.9 Slow release $\mathrm{Zn}$ fertilizer using nano-zeolite as carrier pattern

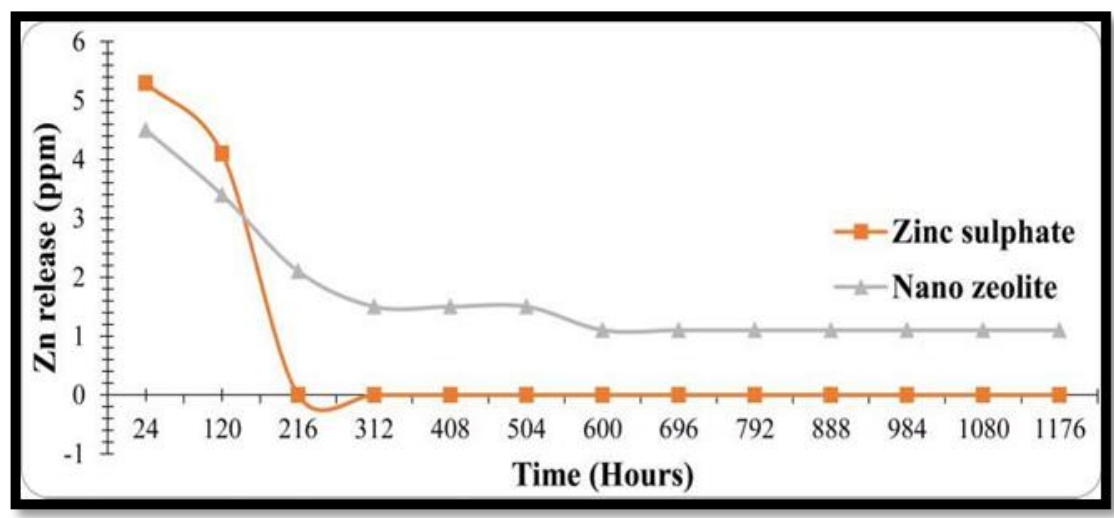

Fig.10 Effect of the enzyme activities of after applying different treatments in Barly crop
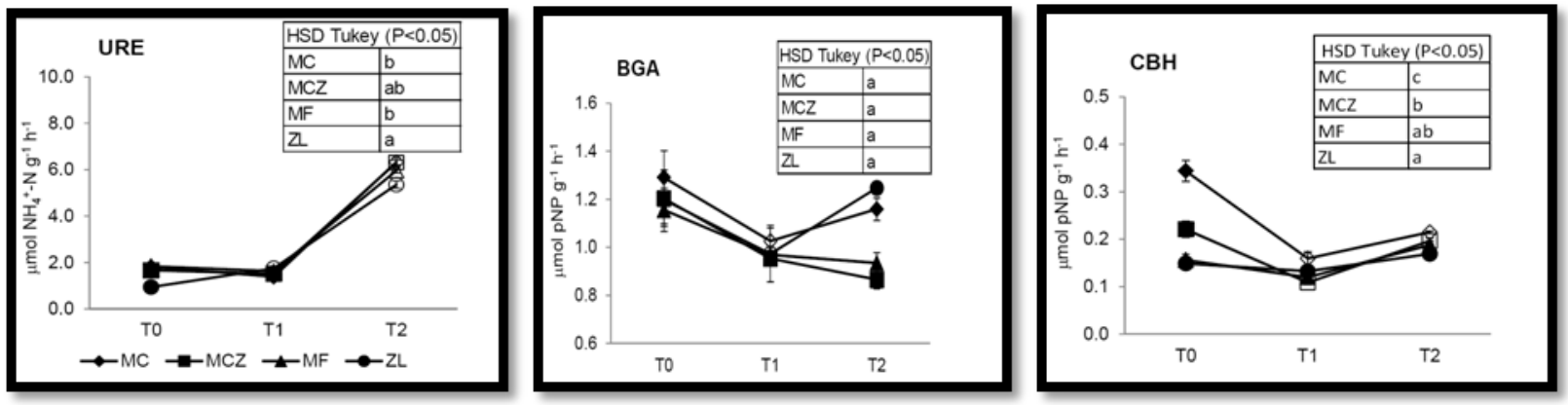

Zeolites are an appropriate material for removing heavy metal ions from wastewater because of their relatively low price coupled with the harmless nature of their exchangeable ions (Barros et al., 2003). Since most zeolites are beneficial for plant growth, it has been demonstrated that certain zeolites with sodium as the main exchangeable cation can actually decrease plant growth and yield. Also, the zeolite erionite is reported to be harmful to health. Therefore, proper selection of appropriate zeolites to suit their 1pplication is important. A few important applications of zeolites have been discussed above, but the possibilities of their usage are much broader. 


\section{Summary}

There is an increasing interest in the utilization of nanoporous zeolites in farming over the years because ofcurrent public concern about the adverse effects of chemical fertilizers on the agro-ecosystem. Ionexchange properties of zeolites are recognized as important for plant nutrition due to their high cation-exchange capacity and porosity. Both ion-exchange and porosity are relevant to agronomy and soil science. The specific structure and diversity of the zeolites vary as also their application. They can be used either as carriers of nutrients and/or a medium to free the nutrients. Several applications have been identified in zeolite research and attempts are being made worldwide. Considerable research has been carried out globally to exploit the potential of zeolites in the perpetual maintenance of soil productivity. The current growing awareness of the phenomenon and availability of inexpensive natural zeolites has aroused considerable commercial interest. Also, a number of issues have been identified for future research.

It is concluded that, zeolites can be used as a potential source of soil conditioner which help in improving soil physico-chemical properties and Biological properties in one way, improving the crop production in others.

\section{The way forwarded}

The following issues have been identifiedfor further research in soil and plant management:

To characterize the Bronsted and Lewis acid centres in zeolites. (Bronsted acid sites are assigned to bridging hydroxyl groups, whereas Lewis acid sites are essentiallyelectronacceptorcentres and they can be cations or different aluminium species located in defect centres; the latter are the so-called true Lewis acid sites).

To probe whether zeolite amendment will reduce the potential for nitrate leaching in agriculture.

To characterize the available zeolite deposits in each country.

To develop methodologies for organo-zeolitic manure/fertilizers.

To characterize the nutrient release pattern from organo-zeolites.

To probe the physical stability of zeolites in a variety of soil environments.

To probe the long-term impact of zeolites on soil flora and fauna.

To develop zeolitic herbicides to minimize herbicidal residues.

To carry out field testing of zeolites on soil and plant systems.

\section{References}

Ahmed, O. H. 2010.Selected growth variables, nutrient uptake, and yield of zea mays 1. Cultivated with cocomposted wastes. Retrieved fromhttp://www.upm.edu.

Barros, M. A. S. D., Zola, A. S., Arroyo, P. A., Sousa-Aguiar, E. F. and Tavares, C. R. G. 2003. Binary ion exchange of metal ions in $\mathrm{Y}$ and $\mathrm{X}$ zeolites.Brazilian Journal of Chemical Engineering 20: $413-421$

Bottero, J.Y., Khatib, K., Thomas, F., Jucker, K., Bersillon, J.L. and Mallevialle, J. 1994.Adsorption of atrazine onto zeolites and organoclays, in presence of background organics.Water Research28: 483-490.

Cairo, J. L. M., Sara, O., Irene, T. and Felipe, B. 2017.Effects of zeolite and organic fertilizers on soil quality and yield of sugarcane.Australian $\quad J . \quad$ Crop Science.11(6):733-738

Hasbullah, N. A.,Ahmed,O. H. and Majid, N. M. 2018.Effect of clinoptilolite zeolite 
on phosphorus dynamics and yield of Zea maize L. cultivated on an acid soil. https://doi.org/10.1371/journal.pone.020 4401

José, L. M., Sara O., Irene T. and Felipe B. 2017.Compost, leonardite, and zeolite impacts on soil microbial community under barley crops.Journal of Soil Science and Plant Nutrition. 17 (1), 214230

Latifah, O., Ahmed, O.H., Susilawati, K., and Majid, N.M. 2015. Compost maturity and nitrogen availability by cocomposting of paddy husk and chicken manure amended with clinoptilotic zeolite. Waste Management and Research.323-331.

Leggo, P. J. 2000. An investigation of plant growth in an organo-zeolitic substrate and its ecological significance.Plantand Soil.219:135-146.

Majid, G. and Amir, G. 2013. Zeoliteamended cattle manure effects on sunflower yield, seed quality, water use efficiency and nutrient leaching. Soil \& Tillage Research.126:193-202

Mehrab, N., Mostafa, C.andSaeid H. 2018.Effect of Raw and NH4 +enriched Zeolite on Nitrogen Uptake by Wheat and Nitrogen Leaching in Soils with Different Textures.Comm.Soil Science and Plant Analysis.47(10): 1306-1316

Mumpton, F.A. 1999.La rocamajica: Uses of natural zeolites in agriculture and industry.(In) Proceedings of National Academy of Science, USA.96:34633470.

Polat, E., Karaca, M., Demir, H. and Onus, A. N. 2004. Use of natural zeolite (clinoptilolite) in agriculture.J.
FruitOrnament. Plant Research.12:183189.

Ramesh, K., Biswas, A.K.andPatra, A. 2015. Zeolitic farming.Indian Journal of Agronomy 60(2): 185-191

Royal Commission of Agriculture.1928. Report of the Royal Commission of Agriculture in India.Part-I.pp.755.

Sangeetha, C. andBaskar, P. 2016. Zeolite and its potential uses in agriculture: A critical review. Agril.Res. Communication Centre.37 (2): 101-108

Sulakhudin, A.S. and Sunarminto , B.H. 2011. Zeolite and hucalcia as coating material for improving quality of NPK fertilizer in costal sandy soil.Journal of Tropical Soils. 16: 99-106.

Tsitsishvili, G. V., Andronikashvili, T. G., Kirov, G. N. and Filizova, L. D. 1992. Natural zeolites, Ellis Horwood Ltd, New York, pp. 295.

Voroney, R. P. and Van Straaten, P. 1988. Use of natural zeolites in sand root zones for putting greens. Greenmaster Magazine .8:19.

Walcarius, A. and Mouchotte, R. 2004. Efficient in vitro paraquat removal via irreversible immobilization into zeolite particles. Archives of Environmental Contamination and Toxicology.46: 135140.

Yasuda, H., Takuma, K., Fukuda, T., Araki, Y., Suzuka, J. and Fukushima, Y. 1998.Effect of zeolite on water and salt control in soil.Bull. Fac. Agric. Tottori Univ. 51: 35-42

Yuvaraj, M. and Subramanian, K. S.2018.Development of slow release $\mathrm{Zn}$ fertilizer using nano-zeolite as carrier.J. plant nutrition.41(3): 311-320.

\section{How to cite this article:}

Binod Kalita, Sarat Sekhar Bora and Bhabesh Gogoi. 2020. Zeolite: A Soil Conditioner. Int.J.Curr.Microbiol.App.Sci. 9(01): 1184-1206. doi: https://doi.org/10.20546/ijcmas.2020.901.133 